\author{
MARCIN R. PAUK \\ Instytut Historyczny \\ Uniwersytetu Warszawskiego
}

\title{
EPISKOPAT, LITURGIA I POLITYKA U SCHYŁKU XI W.: BISKUPI EBERHARD I HENRYK W DOKUMENCIE WŁADYSŁAWA HERMANA DLA KATEDRY BAMBERSKIEJ
}

\author{
Pamięci Profesora Aleksandra Gieysztora w 100 rocznicę urodzin
}

\begin{abstract}
Abstrakt: Artykuł poświęcony jest problematyce wczesnego episkopatu polskiego i norm liturgicznych XI w. z perspektywy identyfikacji postaci biskupów Eberharda i Henryka. Występują oni w dokumencie księcia Władysława Hermana (1079-1102) dla kapituły bamberskiej jako episcopi i fratres katedry bamberskiej. Uznawani byli dotąd w polskiej literaturze za prałatów kapituły, uprawnionych do używania infuł. Autor weryfikuje zasadność tego poglądu na podstawie analizy przywilejów papieskich dotyczących użycia insygniów liturgicznych przez biskupów i kanoników w okresie między X a XII w.
\end{abstract}

Słowa kluczowe: organizacja kościelna w Polsce XI-XII w.; Rzesza, Bamberg i Polska w XI w.; liturgia średniowieczna.
Abstract: This article approaches the questions of the early Polish episcopate and eleventh-century liturgical norms from the viewpoint of an identification of bishops Eberhard and Henry. Both men appear as episcopi and fratres of Bamberg cathedral in a document issued by Duke Władysław Herman (1079-1102) for the chapter of Bamberg. Until now Polish literature has recognized them as prelates of the chapter, entitled to wear infulas. The author has verified the validity of this view through an analysis of papal privileges permitting the use of liturgical insignia by bishops and canons from the tenth to the twelfth century.

Keywords: Church structure in eleventhand twelfth-century Poland, the Reich, Bamberg and Poland in the eleventh century, medieval liturgy.

\section{Eberhard i Henryk: infułaci czy biskupi?}

Niedatowany dokument księcia Władysława Hermana dla kapituły bamberskiej, potwierdzający zwrot zagrabionych kanonikom w nieznanych okolicznościach dwóch złotych krzyży - najpewniej pektorałów - 
i ustanowienie w zamian relacji typu fraternitas plena wraz z prebendą książęcą w tejże kapitule, cieszy się od dziesięcioleci zrozumiałym zainteresowaniem badaczy polskich. Stoi za tym nie tylko fakt, że jest on najstarszym znanym i zachowanym $\mathrm{w}$ oryginale dyplomem, wystawionym $\mathrm{w}$ imieniu polskiego władcy i opieczętowanym jego pieczęcią ${ }^{1}$. Dramatyczny deficyt przekazów z XI w. sprawiał, że oprócz informacji o polskiej organizacji kościelnej schyłku stulecia doszukiwano się w nim także treści politycznych w okresie szczególnie silnych relacji z Rzeszą cesarza Henryka IV. Pomimo tak długiego czasu intensywnych dociekań jedyną $\mathrm{w}$ istocie kwestią, która nie może budzić żadnych wątpliwości, jest ideowy sens przekazanego do Bambergu daru i ustanowionej w ten sposób relacji pomiędzy kanonikami a polskim władcą. Istotą instytucji liturgicznego braterstwa był udział księcia i jego rodziny we wspólnocie modlitewnej kanoników, konkretyzowany obecnością jego wikariuszy w czasie modłów chórowych kapituły i materialnym ekwiwalentem w postaci dziennej racji żywnościowej oraz odzieży, także pożytkowanych przez owych zastępców. Zawiązywanie tego typu relacji między panującym i członkami świeckich elit a różnymi instytucjami kościelnymi było częstą praktyką w okresie rządów dynastii ottońskiej i salic$\mathrm{kiej}^{2}$. Funkcjonowanie tej instytucji z perspektywy religijnej, ale także polityczno-prestiżowej, jak również jej znaczenie dla polskich władców na szerokim tle kultury politycznej i religijnej Europy X-XII w. scharakteryzował wyczerpująco Roman Michałowski³ ${ }^{3}$.

${ }^{1}$ Reprodukcja i wydanie: Album palaeographicum, wyd. S. Krzyżanowski, Kraków 1935, nr 1; edycja wraz z przekładem także J. Szymański, Nauki pomocnicze historii, Warszawa 2001, s. 707; Z. Kozłowska-Budkowa, Repertorium polskich dokumentów doby piastowskiej, z. 1: Do końca wieku XII, Kraków 2006 (wyd. 2), nr 14, s. 69-71, gdzie omówienie starszej literatury; ostatnio T. Jurek, Początki dokumentu polskiego, w: Dyplomatyka staropolska, red. idem, Warszawa 2015, s. 68-69.

2 Ostatnio obszernie W.E. Wagner, Die liturgische Gegenwart des abwesenden Königs. Gebetsverbrüderung und Herrscherbild im frühen Mittelalter, Leiden 2010, Brill's Series on the Early Middle Ages, t. 19, s. 41-162; J. Fleckenstein, Rex canonicus. Über Entstehung und Bedeutung des mittelalterlichen Königskanonikates, w: idem, Ordnungen und formende Kräfte des Mittelalters. Ausgewählte Beiträge, Göttingen 1989, s. 193-210; H. Boockmann, Eine Urkunde Konrads II. für das Damenstift Obermünster in Regensburg. Zu einem verschenkten Königsszepter und zum Königskanonikat, w: Institutionen, Kultur und Gesellschaft im Mittelalter. Festschrift für Josef Fleckenstein zu seinem 65. Geburtstag, red. L. Fenske, W. Rösener, T. Zotz, Sigmaringen 1984, s. 207-219; na temat odróżnienia fraternitas od późniejszego stałego kanonikatu władcy w kapitule: M. Groten, Von dem Gebetsverbrüderung zum Königskanonikat. $\mathrm{Zu}$ Vorgeschichte und Entwicklung der Königskanonikate an den Dom- und Stiftskirchen des Deutschen Reiches, „Historisches Jahrbuch” 103, 1983, s. 1-34.

${ }^{3}$ R. Michałowski, Princeps fundator. Studium z dziejów kultury politycznej $w$ Polsce XXIII wieku, Warszawa 1993, s. 106-110; idem, Bolesław Chrobry bratem kanoników magde- 
Okoliczności samej donacji Władysława Hermana są jednak dalekie od klarowności, a jak wynika z samego dyplomu, nie ograniczyła się ona tylko do zwrotu rzeczonych krzyży. Nie wiadomo też, w jaki sposób katedra bamberska utraciła owe cenne przedmioty liturgiczne oraz od kogo zostały one odkupione przez księcia ${ }^{4}$. Kontrowersje badawcze związane były także z identyfikacją dwóch z czterech występujących w dyplomie duchownych - mianowicie Eberharda i Henryka, określonych jako episcopi i fratres eiusdem (tj. bamberskiej) ecclesie ${ }^{5}$. Za zaliczeniem ich do grona polskiego episkopatu optował przede wszystkim Tadeusz Wojciechowski, który dokumentowi Władysława Hermana poświęcił sporo uwagi w uzupełnieniach do swych Szkiców historycznych jedenastego wieku ${ }^{6}$. Jego wystawienie datował na lata 1084 lub 1085 i uznawał za ślad kontaktów dyplomatycznych z Henrykiem IV. Nawiązując do poglądów formułowanych w literaturze niemieckiej, wyraził przekonanie - skądinąd w mojej opinii całkowicie słusznie - że jest całkiem nielogiczne, by po zwrot utraconych przedmiotów kanonicy bamberscy wysyłali do Polski dwóch biskupów niemieckich z innych diecezji. Uznając niemieckie pochodzenie Eberharda i Henryka, zgodnie z ówczesnym stanem wiedzy na temat polskiej organizacji kościelnej w końcu XI w., zidentyfikował ich zatem jako biskupów Wrocławia i Płocka ${ }^{7}$. Dopatrywał się

burskich. Próba nowego spojrzenia, KH 112, 2005, 3, s. 55-68; nieco odmienny obraz tej instytucji, wynikający przede wszystkim z nieuwzględnienia kluczowych dla X-XI w. źródeł niemieckich: M. Derwich, Kanonicy świeccy, Bolesław Chrobry i Magdeburg. Ze studiów nad „zapomniana” instytucją kościelna, w: Viae historicae. Księga jubileuszowa dedykowana Profesorowi Lechowi A. Tyszkiewiczowi w siedemdziesiąta rocznicę urodzin, red. M. Goliński, S. Rosik, Wrocław 2001, s. 233-241.

${ }^{4}$ Tzw. Pouczenie Włodzimierza Monomacha, włączone do Powieści minionych lat pod rokiem 1096, zawiera informację o odbytej dwadzieścia lat wcześniej czteromiesięcznej wyprawie wojennej ruskiego księcia przeciw Czechom w sojuszu z Bolesławem Szczodrym. Nie wiadomo dokładnie, jaki region latopisarz ruski miał na myśli, pisząc o Czeskim Lesie jako miejscu działań wojennych Monomacha, ale nazwą tą określa się pasmo górskie oddzielające od zachodu Czechy od wschodniej Frankonii, położone w niewielkiej odległości od Bambergu. Trudno ocenić, czy ruscy wojownicy mogliby dotrzeć tak daleko na zachód i zrabować przy tej okazji przedmioty należące do kapituły bamberskiej, ale konieczność odkupienia ich przez Władysława Hermana za wysoką sumę sugerować może, że był to łup wojenny ówczesnych sojuszników. Oba wydarzenia dzieli jednak duża odległość w czasie, co oczywiście osłabia przedstawioną tu hipotezę; zob. Повесть временных лет, wyd. Д.С. Лихачев, Москва-Ленинград 1950, s. 159.

${ }^{5}$ „duas aureas cruces [--] interpellante G[umpone] nuncio fratrum et domini Ruotperti eiusdem loci VII episcopi, reddiderim per manus Eberhardi et Heinrici episcoporum, eiusdem Babenbergensis ecclesie fratrum", Album palaeographicum, $\mathrm{nr} 1$.

${ }^{6}$ T. Wojciechowski, Szkice historyczne jedenastego wieku, Warszawa 1951 (wyd. 3), s. 274-278.

${ }^{7}$ Ibidem, s. 285-286. 
wyraźnie politycznych motywów zaangażowania i obecności bamberczyków w Polsce, konkludując: „tak czy owak, mamy tu nowy dowód na to, że między Hermanem a Bambergiem były jakieś stosunki nie tylko dawniejsze, ale i niezwykle bliskie". Wątpliwości badacza nie wzbudzały tylko ich godność biskupia, pochodzenie z Rzeszy i fakt przynależności do kapituły bamberskiej, wyrażony wprost w interesującym nas dyplomie. Określenia „fratres eiusdem ecclesie” Wojciechowski nie potrafił jednoznacznie wytłumaczyć, dywagując nad ewentualnym połączeniem przez nich godności biskupich w Polsce $\mathrm{z}$ kanonickimi w Bambergu. Erudycja autora wprowadziła go jednak na trop podjęty przez następców: Wojciechowski dostrzegł bowiem, że w interesującym go okresie wystąpili w innych źródłach bamberskich dziekan Eberhard i kustosz Henryk. Badacz zasygnalizował ich ewentualną tożsamość z postaciami z dokumentu Władysława Hermana, jednak nie umiał wyjaśnić, dlaczego prałatom kapituły miano by przyznać tytuł biskupów ${ }^{8}$. Do koncepcji tej powrócił po latach Aleksander Gieysztor. Od czasu jego opublikowanego w 1970 r. studium pt. Bamberg i Polska w XI i XII wieku kwestia identyfikacji owych postaci wydawać się mogła ostatecznie wyjaśniona. Uczony przyjął bowiem pogląd Johanna Looshorna, dziewiętnastowiecznego regionalnego badacza dziejów biskupstwa bamberskiego i autora wielotomowej monografii, który we wzmiance o donacji Władysława Hermana zauważył, że interesujący nas duchowni to aktualni dziekan i kustosz kapituły bamberskiej, uprawnieni do noszenia infuł (czy też mitr) na mocy przywileju papieskiego ${ }^{9}$. Interpretację tę uznał za właściwą także Erich von Guttenberg w edycji regestów bamberskich, a rozwinął Gieysztor, wskazując na przywilej papieża Leona IX z 1052 r. dla kapituły bamberskiej, uprawniający tamtejszych kanoników do używania owych nakryć głowy w czasie celebracji mszy w ściśle określone święta roku liturgicznego ${ }^{10}$. Zaczerpnięty z papieskiego przywileju katalog tych świąt - skądinąd zresztą niezbyt obszerny - zamieścił autor w przypisie i nie poświęcił mu zbytniej uwagi. Eberhard i Henryk w czasie misji w Polsce mieli być zatem nie biskupami, lecz prałatami - infułatami kapituły bamberskiej, okres zaś ich wspólnego urzędowania, odpowiednio jako dziekana i kustosza, ustalony w przybliżeniu na podstawie źródeł niemieckich na lata 1087-1095, datował także wystawienie omawianego dyplomu. Opinia Looshorna, według którego otoczenie księcia polskiego -

8 Odnotował tę wiedzę jedynie w przypisie, ibidem, s. 370.

9 J. Looshorn, Die Geschichte des Bistums Bamberg, t. 1, München 1886, s. 485-486; zob. także Die Regesten der Bischöfe und des Domkapitels von Bamberg, wyd. E. Freiherr von Guttenberg, Würzburg 1963, nr 551.

10 A. Gieysztor, Bamberg i Polska w XI i XII wieku, St. Źr. 15, 1970, s. 73-75. 
wystawcy dyplomu - ze względu na używanie infuł przez obu dygnitarzy nie zorientowało się, że $\mathrm{w}$ istocie nie ma do czynienia z biskupami, nie wydała się jednak warszawskiemu historykowi przekonująca. Implikowała ona także, że dokument potwierdzający donację i uzyskanie prebendy został sporządzony wyłącznie przez stronę polską, całkowicie bez udziału bamberskich gości, co jest dalekie od ostatecznego rozstrzygnięcia, a w opinii wielu autorów ze względu na cechy zewnętrzne raczej mało prawdopodobne ${ }^{11}$. Tytuły biskupów przydane obu duchownym próbował Gieysztor wytłumaczyć raczej względami honorowymi i grzecznościowymi. Prałaci bamberscy mieli zatem wybrać się w podróż do Polski wraz ze swymi infułami, by celebrować w nich liturgię w święta wyszczególnione w papieskim przywileju. „Dni było tyle i rozsianych w ciągu roku kościelnego, że obaj dygnitarze bamberscy mogli byli pojawić się w Polsce z oznakami swego przywileju liturgicznego w każdej porze roku, a kancelaria - kaplica pałacowa władcy polskiego uczciła to, przypisując im tytuł biskupi" - konkludował badacz ${ }^{12}$.

Utrwalona autorytetem naukowym Gieysztora identyfikacja nie wzbudziła jak dotąd żadnych wątpliwości i została powszechnie przyjęta wraz z zaproponowaną na jej podstawie datacją dyplomu ${ }^{13}$. Badacz w bardzo skrótowym - przyznać trzeba - wywodzie nie podją jednak próby rozstrzygnięcia kilku podstawowych dla tematu kwestii, które postawić wypada po krytycznej analizie jego argumentacji. Jest ona bowiem obarczona dużą liczbą apriorycznych i bardzo kontrowersyjnych założeń. Przede wszystkim zakłada całkowitą dowolność w pełni świadomego posługiwania się w Polsce tytułem biskupim, używanym jak chciał Gieysztor - także ze względów kurtuazyjnych wobec osób, które święceń biskupich ani inwestytury nie otrzymały, ani też same za biskupów się nie podawały. Implikuje ponadto całkowitą jednoznaczność w odczycie znaczenia elementu stroju liturgicznego - tj. infuły u schyłku

${ }^{11}$ Za bamberskim ingrossatorem opowiedziała się Z. Kozłowska-Budkowa, op. cit., nr 14, s. 71.

12 A. Gieysztor, op. cit., s. 74.

${ }^{13}$ Por. J. Strzelczyk, Bamberg a Polska w średniowieczu, RH 62, 1996, s. 78; P. Wiszewski, Domus Bolezlai. W poszukiwaniu tradycji dynastycznej Piastów (do około 1138 roku), Wrocław 2008, s. 95, autor na tej podstawie wyciągnął logiczny skądinąd wniosek, że dokument nie mógł wyjść spod ręki ingrossatora bamberskiego, który nie przydałby prałatom własnej kapituły miana biskupów; ostatnio także, jakkolwiek bez nowej analizy problemu i z ograniczeniem się jedynie do zreferowania starszych poglądów K. Benyskiewicz, Władysław Herman książę Polski 1079-1102, Kraków 2014, s. 248-249, oraz A. Krawiec, Król bez korony. Władysław I Herman ksiazże polski, Warszawa 2014, s. 165, próbujący na tej podstawie podważać tezę o dominacji obcoetnicznego kleru w polskim episkopacie drugiej połowy XI w. 
XI w. jako insygnium biskupiego (obojętnie, czy ze świadomością, że posługujące się nią osoby biskupami nie są - jak przyjmował polski badacz, czy bez tej świadomości - jak zakładał Looshorn). Wreszcie, co chyba najistotniejsze, uczony uznać musiał chyba (choć wprost nigdzie tego nie wyraził), że przywilej Leona IX z 1052 r. upoważniał każdego z prałatów i kanoników bamberskich do indywidualnego posługiwania się rzeczonymi infułami wszędzie, gdzie tylko wypadło im odprawiać liturgię w wyznaczone $\mathrm{w}$ dokumencie święta, a zatem jego dyspozycja przypominała dużo powszechniejsze w interesującej nas epoce osobowe przywileje dla metropolitów - a sporadycznie także dla innych biskupów - na używanie paliusza oraz innych insygniów władzy arcybiskupiej.

II. Przywilej Leona IX dla kanoników bamberskich i jego jedenastowieczne konteksty

Weryfikację założeń Gieysztora wypada rozpoczać właśnie od tego ostatniego punktu, nie tylko dlatego, że w tym przypadku wydaje się ona najłatwiejsza do przeprowadzenia, ale także z tego względu, że w zależności od jej wyniku zaistnieje lub nie konieczność odpowiedzi na dwie pozostałe kwestie. Na wstępie zastrzec trzeba, iż znaczenie interesującego nas przywileju papieskiego z 9 października 1052 r. dla kanoników katedry bamberskiej rozpatrywać trzeba nierozłącznie z wystawionym nieco później przywilejem dla biskupa bamberskiego Hartwiga na używanie paliusza z 2 stycznia 1053 r. Pierwszy z nich wystawiony został w Treburze, niespełna miesiąc po poświadczonym 18 października pobycie papieża w Bambergu. Oryginały obu przechowywane są do dzisiaj w Bayerisches Hauptstaatsarchiv (BHStA) w Monachium, ale wczesne odpisy odnaleźć można w sporządzonym ok. 1125 r. bamberskim kopiariuszu dokumentów i listów, tzw. Codex Udalrici, oraz w późniejszym o kilkadziesiąt lat żywocie cesarza Henryka II autorstwa Adalberona ${ }^{14}$.

Kluczową częścią dyspozycji jest zezwolenie przez Leona IX na używanie mitr jako elementu stroju liturgicznego przez prezbitrów i diakonów wybranych przez biskupa z grona kapituły. Kryterium owego wyboru miały być ich cnoty osobiste, wiek lub godności przełożonych zgromadzenia ${ }^{15}$.

${ }^{14}$ Edycje dyplomów: Sancti Leonis IX epistolae et decreta pontificia, PL, t. 143, nr 75 i 76; Die Vita sancti Heinrici regis et confessoris, wyd. M. Stumpf, Hannover 1999, MGH SrG, t. 69, s. 262-270; zob. także Die Regesten der Bischöfe, nr 258 i 260; Regesta pontificum Romanorum, t. 1, wyd. P. Jaffé, Lipsiae 1885, nr 4283 i 4287.

15 Brzmienie przywileju z zaznaczeniem kluczowych dla dalszej argumentacji fragmentów podaję za najnowszą edycją w Die Vita sancti Heinrici regis, s. 269-270: 
W tekście nie użyto co prawda sformułowania „inter missarum solempnia", zazwyczaj spotykanego w przywilejach dla arcybiskupów na używanie paliusza, ale było to dla obu stron oczywiste. Dyplom papieski, podobnie jak dużo liczniejsze między IX a XII w. zezwolenia dla arcybiskupów na używanie paliusza oraz innych insygniów władzy metropolitalnej (tj. np. krzyż procesyjny, mitra, liturgiczny kropierz na konia, używany w czasie liturgii stacyjnej naccus), zawiera katalog świąt kościelnych, w które przywilej ten miał być realizowany ${ }^{16}$. Ich skład obejmował główne święta chrześcijańskie roku liturgicznego - w przypadku kanoników bamberskich były to Boże Narodzenie, Wielki Czwartek, Wielka Sobota, Wielkanoc i Pięćdziesiątnica oraz dni świętych patronów wyróżnionego kościoła, którymi dla katedry bamberskiej byli św. Jerzy, św. św. Piotr i Paweł oraz Najświętsza Maria Panna (Wniebowzięcie). W analizowanym katalogu przywileju Leona IX szczególną uwagę zwrócić należy jednak na dwie okazje do liturgicznego użycia mitr, niezwiązane z kultem

„Deliberatis igitur, sanccitis ac corroboratis omnibus supra dictis rebus, eidem sancto loco placuit addendum insigne honoris aecclesiasticis nostra apostolica auctoritate, ducti amore et reverentia Clementis, piae memoriae praedecessoris nostri quem Deus miro dispositioni ordine a praelatione huius loci ad sancte Romane catholice et apostolice aecclesie apicem dignatus est accersire, et mirabilius e Romanis finitimis defunctum corpus eius reducere, volens hanc aecclesiam, ut estimamus, quasi novam tanto decoratam esse patrono, Romanamque contentam et sufficientem praeteritis et futuris patribus manere ornatam, quin etiam amore et desiderio fratrum, qui nos in suis recepere ecclesiasticis stipendiis et cottidianis, unum nostra vicissitudine regere fratrem, mitras gestandi concedimus licentiam, ea scilicet ratione, ut ab episcopo provideantur digniores et honestiores presbyteri et diaconi, qui bonis moribus vel maturis etatibus vel etiam prelationibus ipsius loci emineant his videlicet diebus: in nativitate domini et salvatoris nostri Ihesu Christi, et in coena domini, et in sabbato sancto, et in die gloriose resurrectionis eiusdem, et sancto pentecosten, et in die sancti Georgii, et in die sanctorum Petri et Pauli et assumptionis beatissime Marie, et sancti Dionisii, pro reverentia nostri praelibati praedecessori domni Clementis papae, cuius anniversarius dies tunc ab eisdem fratribus agitur, et in anniversario die domni Heinrici imperatoris, eiusdem loci venerabilis constructoris. His vero concedimus hanc dignitatem, qui tantum specialiter excubant vel deserviunt apud predicti predecessoris nostri sepulchrum. Contentostamen his sancimus diebus fore, nec ultra a quoquam temere usurpari, ne honor proprius apostolice sedis vilescat. Haec vero omnia supra dicta observari et custodiri in perpetuum, nostra apostolica auctoritate decernimus, confirmamus et corroboramus" (wyróżnienia - M.R.P.).

${ }^{16} \mathrm{Na}$ temat dyplomów papieskich dotyczących nadań paliusza oraz innych liturgicznych uprawnień honorowych dla odbiorców niemieckich w okresie poprzedzającym pontyfikat Leona IX zob. J. Johrendt, Papsttum und Landeskirchen im Spiegel der päpstlichen Urkunden (896-1046), Hannover 2004, MGH Studien und Texte, t. 33, s. 65-68 i $169-176$. 
Chrystusa i świętych patronów. Zanim jednak poświęcimy uwagę temu zagadnieniu, wyjaśnienia wymaga samo znaczenie przyznawania przez papiestwo szczególnych przywilejów liturgicznych w XI w.

Sformułowania pojawiające się w papieskich przywilejach na używanie specjalnych insygniów i atrybutów liturgicznych - czy to arcybiskupiego paliusza, mitry w przypadku biskupów i kanoników, czy w przypadku sandałów i dalmatyki w przypadku opatów - nie pozostawiają wątpliwości, że celem ich przyznania było podkreślenie szczególnej więzi łączącej wyróżnionego hierarchę lub całą instytucję ze Stolicą Apostolską. Chyba najdobitniej idea ta wyrażona została w przywileju paliuszowym dla metropolity mogunckiego Willigisa z 975 r.: „Chętnie przyznajemy waszej braterskości prawo używania paliusza, które dla ozdoby urzędu kapłańskiego oraz dla okazania jedności, jaką ze świętym Piotrem powinno mieć całe powierzone mu stado owiec Pańskich, wyprosiliście zgodnie z powinnością u Stolicy Apostolskiej"17. Natura owych relacji z papiestwem - istniejących już wcześniej lub dopiero nawiązywanych wraz z uzyskaniem przywileju - mogła być bardzo rozmaita. Jako powód wyróżnienia arcybiskupa trewirskiego Eberharda prymatem kościelnym na obszarze dawnej rzymskiej prowincji Galia Belgica w 1049 r. papież Leon IX - za którego pontyfikatu rozdawnictwo honorów liturgicznych weszło w nową fazę - wskazał kult, którym otaczano w Trewirze nie tyle samego patrona katedry - św. Piotra, ile św. św. Euchariusza, Waleriusza i Materna, uznawanych za jego uczniów. Wizualizacją trewirskiego ius primatum i związku z apostołem miało być posługiwanie się w liturgii przez metropolitę i jego następców „rzymską” mitrą: „dla nadania owego prymatu głowę waszą odznaczyliśmy rzymską mitrą, którą i wy, i wasi następcy będą zawsze używać w kościelnych obrzędach i zawsze wspominać, że jesteście uczniami stolicy rzymskiej"18.

17 „Palii interea usum, quem ad sacerdotalis officii decorem et ad ostendendam unanimitatem, quam cum beato Petro apostolo universus grex dominicarum ovium, que ei comisse sunt, habere debet, a sede apostolica, sicut debet, poposcisti, libenter fraternitati tue concessimus", Papsturkunden 846-1046, wyd. H. Zimmermann, t. 1, Wien 1984 (dalej: PU), nr 237.

18 „pro investitura ipsius primatis Romana mitra caput vestrum insignivimus, qua et vos et successores vestri in ecclesiasticis officiis Romano more semper utemini, semperque vos esse Romane sedis discipulos reminiscemini", Sancti Leonis IX epistolae et decreta, $\mathrm{nr}$ 3. Idea specjalnych prerogatyw prymasowskich metropolitów trewirskich, mających wynikać z faktu sukcesji po uczniach św. Piotra oraz ordynowania św. Euchariusza, pierwszego biskupa Trewiru, przez samego apostoła, pojawiła się już wcześniej w dyplomach Jana XIII i Benedykta VII dla arcybiskupa Dytryka I (PU, t. 1, nr 195 i 235). Dokument Benedykta VII, datowany na 975 r., ustanowił ponadto kolegium kardynałów prezbitrów i diakonów, mających prawo odprawiać liturgię w dalmatykach i sandałach. 
Zauważyć w tym miejscu warto, że możliwość wykazania jak największej bliskości relacji z Rzymem, czy wręcz prestiżowego liturgicznego i ustrojowego „upodobnienia” kościoła metropolitalnego do Stolicy Apostolskiej, była dla arcybiskupów Rzeszy na przełomie X i XI w. drogą do potwierdzenia swego prymatu w kościele Cesarstwa, a w przypadku Magdeburga przynajmniej wyrównania statusu wobec starszych metropolii. Ten ostatni przykład jest znamienny, gdyż zaowocował szeroką akcją fałszowania i interpolowania papieskich przywilejów, w których aequalitas, a nawet szczególny status nadłabskiej metropolii podkreślone zostały nie tylko prawem używania paliusza i krzyża procesyjnego przez metropolitę, ale też ograniczeniem prawa jego konsekracji wyłącznie do osoby legata papieskiego, zapewnienia arcybiskupowi consortium kardynałów Kurii Rzymskiej, jak również ustanowienia w katedrze magdeburskiej kolegium kardynałów prezbitrów i diakonów uprawnionych do używania dalmatyk i sandałów w czasie celebracji liturgicznych ${ }^{19}$. W przypadku arcybiskupstwa kolońskiego i przywileju Leona IX dla arcybiskupa Hermana II z 1052 r. na używanie paliusza, krzyża metropolitalnego i naccus wystarczyło odwołanie się do wspólnego dla obu kościołów patrocinium św. Piotra ${ }^{20}$. Szczególny charakter arcybiskupiego nakrycia głowy jako elementu „odtwarzania” liturgii rzymskiej poza Rzymem podkreślony

Oba dyplomy wzbudzają poważne kontrowersje co do swej autentyczności i obecnie są raczej uznawane za falsyfikaty z drugiego dziesięciolecia XI w., co nie zmienia faktu podkreślania ścisłych związków metropolii z Rzymem dla umocnienia jej uprzywilejowanej pozycji; zob. też E. Boshof, Das Erzstift Trier und seine Stellung zu Königtum und Papsttum im ausgehenden 10. Jahrhundert. Der Pontifikat des Teoderich, Köln-Wien 1972, s. 42-80; zob. także R. Michałowski, Zjazd gnieźnieński. Religijne przesłanki powstania arcybiskupstwa gnieźnieńskiego, Wrocław 2005, s. 32-38.

19 Zob. zwłaszcza PU, t. 1, nr 270; PU, t. 2, Wien 1985, nr 412, 473, 473. Złożone kwestie źródłoznawcze związane z genezą, dyspozycją i datacją dokumentów magdeburskich omówił obszernie Helmut Beumann, Theutonum nova metropolis. Studien zur Geschichte des Erzbistums Magdeburg in ottonischer Zeit, Köln-Weimar-Wien 2000, Quellen und Forschungen zur Geschichte Sachsen-Anhalts, t. 1; zob. o tej samej kwestii z perspektywy katalogów świąt z użyciem paliusza także T. Zotz, „Pallium et alia quaedam archiepiscopatus insignia”. Zum Beziehungsgefüge und zu Rangfragen der Reichskirchen im Spiegel der päpstlichen Privilegierung des 10. und 11. Jahrhunderts, w: Festschrift für Berent Schwineköper, red. H. Maurer, H. Patze, Sigmaringen 1982, s. 155-175.

20 „praesertim cum ecclesia haec sub nomine principis apostolorum beatissimi Petri sit consecrata sicut mater sua, cui praesidemus divina clementia, ut quae matrem imitatur ex nomine filia imitetur aliquantisper in dignitate protegaturque sub aliis defensionis suae", H. Wolter, Das Privileg Leos IX. Für die Kölner Kirche vom 7. Mai 1052 (JL. 4271), w: E. Boshof, H. Wolter, Rechtsgeschichtlich-diplomatische Studien zu frühmittelalterliche Papsturkunden, Köln-Wien 1976, s. 113. Tam również obszerna analiza dyplomatyczna przywileju. 
został jeszcze w dwunastowiecznym falsyfikacie przywileju paliuszowego arcybiskupa hambursko-bremeńskiego Hogera, sporządzonym za pontyfikatu Hartwiga I (1148-1168), w którym przyznana została hierarsze „mitra, quod est insigne Romanorum”21. Powodem przyznania liturgicznego wyróżnienia dla opata - tj. sandałów i dalmatyki - mogła być zwykła egzempcja papieska lub szczególna protekcja (mundiburdium sancti Petri) nad klasztorem, jak w przypadku opactwa w Fuldzie ${ }^{22}$. Na wyjątkową uwagę - także z innych względów, o których niżej - zasługuje z pewnością przypadek uzyskania przez biskupa halbersztadzkiego Burcharda II prawa do posługiwania się paliuszem, które nadał mu w 1063 r. papież Aleksander II. Saskie biskupstwo nie miało nigdy ambicji metropolitalnych, ani też nie mogło wykazać się wcześniej szczególną relacją z papiestwem, powody zaś wyróżnienia liturgicznego dla biskupa i jego kanoników w postaci m.in. paliusza i infuł tkwiły wyłącznie w bieżących uwarunkowaniach politycznych. Burchard II wysłany został w tymże 1063 r. do Rzymu przez swego wuja, arcybiskupa kolońskiego Annona II - sprawującego ówcześnie rządy regencyjne w imieniu małoletniego Henryka IV. Zadaniem biskupa było zakończenie schizmy Kadalusa z Parmy i uznanie legalności wyboru Aleksandra II na tron Piotrowy. Przywilej papieski był zatem formą odwdzięczenia się biskupowi za wykonaną po myśli Aleksandra II misję dyplomatyczną 23 . To wystarczyło, by nadać kościołowi halbersztadzkiemu tytuł „filie Romane ecclesie”, a jego zwierzchnikowi przywilej posługiwania się insygniami przyznawanymi dotąd jedynie metropolitom - paliuszem, mitrą, krzyżem procesyjnymi i naccus, kanonikom zaś prawo odprawiania liturgii w mitrach ${ }^{24}$.

Związki biskupstwa bamberskiego z papiestwem daleko wyprzedzają pontyfikat Swidgera - Klemensa II i przywilej Leona IX, gdyż nawiązane zostały już na początku istnienia wschodniofrankońskiej diecezji za sprawą króla Henryka II, który powierzył dedykowaną świętym apostołom Piotrowi i Pawłowi fundację pod protekcję papieską. W 1007 r. uzyskała ona od Jana XVIII przywilej obejmujący nowe biskupstwo Romanum

${ }^{21}$ PU, t. 1, nr 32; o falsyfikatach hamburskich obszerniej W. Seegrün, Das Erzbistum Hamburg in seinen älteren Papsturkunden, Köln-Wien 1976, s. 63-82.

22 PU, t. 2, nr 339, 599.

23 Obszernie na ten temat: H. Beumann, Zu den Pontifikalinsignien und zum Amtsverständnis der Bischöfe von Halberstadt im hohen Mittelalter, „Sachsen und Anhalt” 18, 1994, s. 9-25; także M. Kleinen, Bischof und Reform. Burchard II von Halberstadt (1059-1088) und die Klosterreform, Husum 2004, s. 67-72.

${ }^{24}$ Urkundenbuch des Hochstifts Halberstadt und seiner Bischöfe, wyd. G. Schmidt, t. 1, Leipzig 1883, nr 83; zob. także protest arcybiskupa mogunckiego Zygfryda w tej sprawie, skierowany do Aleksandra II - ibidem, nr 89. 
mundiburdium - co niebagatelne - motywowanym myślą o lepszym zabezpieczeniu $\mathrm{w}$ ten sposób trwałości memorii liturgicznej królewskiego fundatora. Przywodzi to na myśl obawy Henryka II o przyszły los swego biskupstwa, którego prawomocność była ciągle kontestowana przez biskupa würzburskiego ${ }^{25}$. Zacieśnienie relacji z Rzymem przyniosła wizyta Benedykta VIII w Bambergu na Wielkanoc 1020 r., odbyta także na zaproszenie cesarza z okazji konsekracji kolegiaty św. Szczepana ${ }^{26}$. Odnowiony przy tej okazji przywilej protekcyjny nie zaowocował jednak jeszcze wtedy ani papieską egzempcją z podległości metropolitalnej względem Moguncji, ani też przyznaniem biskupowi i kanonikom bamberskim oznak owego szczególnego statusu w formie „rzymskich” utensyliów liturgicznych. Materialnym desygnatem owej protekcji św. Piotra stał się wtedy jedynie dar rekognicyjny w postaci białego wierzchowca wraz z siodłem, wysyłany corocznie papieżowi ${ }^{27}$.

W tym miejscu wrócić musimy do zawieszonego wyżej wątku dni świątecznych, w których kanonikom bamberskim przysługiwało prawo użycia infuł w czasie liturgii. Lektura tekstu przywileju Leona IX z 1049 r. nie pozostawia wątpliwości co do nierozerwalnego związku pomiędzy liturgicznym wyróżnieniem kapituły a dwoma kwestiami. Pierwszą i bez wątpienia najważniejszą kwestią jest liturgia komemoracyjna pochowanych w katedrze osób. Jednym z nich jest oczywiście fundator katedry - cesarz Henryk II $^{28}$. Na liście świąt zwraca jednak uwagę zwłaszcza odnotowanie dnia św. Dionizego. Stało się tak bynajmniej nie z powodu szczególnego kultu, którym w Bambergu miano by otaczać tego świętego, lecz - co zostało objaśnione w samym dokumencie papieskim -

25 „sit ille episcopatus liber ab omni extranea potestate securus, Romano tantummodo mundiburdio subditus, quatenus episcopus eo melius cum canonicis suis servitio Dei possit insistere et primi constructoris eiusdem ecclesie et recuperatoris iugiter memoriam habere", PU, t. 2, nr 435. Zob. H. Hoffmann, Mönchskönig und rex idiota. Studien zu Kirchenpolitik Heinrichs II und Konrads II, Hannover 1993, MGH Studien und Texte, t. 8, s. 85-91.

${ }^{26}$ S. Pflefka, Auf dem Weg zur Exemtion. Die Privilegierung der Bamberger Kirche im 11. und frühen 12. Jahrhundert, „Berichte des Historischen Vereins Bamberg” 138, 2002, s. 140-150, zob. też K.-J. Benz, Untersuchungen zur politischen Bedeutung der Kirchweihe unter Teilnahme der deutschen Herrscher im hohen Mittelalter. Ein Beitrag zum Studium des Verhältnisses zwischen weltlicher Macht und kirchlicher Wirklichkeit unter Otto III. und Heinrich II., Kallmünz 1975, s. 166-176.

${ }^{27}$ PU, t. 2, nr 528. O podstawach ideowych biskupstwa obszerniej M.R. Pauk, „Arcem Romanam se gestit habere coequam". Biskupstwo bamberskie $w$ krajobrazie politycznym Rzeszy do połowy XII wieku, w: Biskup Otto z Bambergu i jego świat, red. M. Rębkowski, Szczecin 2017 (w druku).

${ }^{28} \mathrm{Na}$ istnienie osobnego ordo mszy anniwersaryjnej za Henryka II i jego żonę Kunegundę wskazują zachowane formuły bamberskie z drugiej ćwierci XI w., zob. H. Hoffmann, op. cit., s. 200-201. 
ze względu na anniwersarz papieża Klemensa II (1046-1047) ${ }^{29}$. Bezpośredni, nie licząc niezwykle krótkiego pontyfikatu Damazego II (1048), poprzednik Leona IX był pierwszym z szeregu niemieckich nominatów Henryka III na tronie papieskim, wcześniej zaś piastował od 1040 r. godność biskupa bamberskiego, z której jednak nie zrezygnował, stając się papieżem ${ }^{30}$. W czasie krótkiego pontyfikatu związki Swidgera-Klemensa II ze swym pierwszym biskupstwem pozostały bardzo silne, czego dowodem jest przywilej o niezwykłej stylizacji, potwierdzający wcześniejszy status diecezji objętej protekcją św. Piotra, w którym papież personifikująco zwracał się do swego pierwszego biskupstwa w drugiej osobie liczby pojedynczej, jako swej oblubienicy („,karissima filia Babenberch, sponsa dulcissima") ${ }^{31}$. Konsekwencją tej predylekcji była ostatnia wola zmarłego nieoczekiwanie już w 1047 r. Klemensa II, by spocząć po śmierci w katedrze bamberskiej. Ciało papieża istotnie zostało wkrótce złożone w dedykowanym św. Piotrowi głównym, zachodnim chórze kościoła katedralnego ${ }^{32}$. Tak jak pochówek otoczonego kultem cesarskiego fundatora legitymizować miał samo istnienie biskupstwa, tak grób papieski stał się zapewne bardzo znaczącym materialnym potwierdzeniem mundiburdium Romanum i związków ze stolicą chrześcijańskiego świata. Należy w tym miejscu dodać, że katalog świąt zawarty w przywileju paliuszowym tegoż Leona IX dla biskupa Hartwiga z początku 1053 r. jest dużo mniej obszerny - zezwala bowiem jedynie na trzykrotne użycie tego insygnium w roku liturgicznym - w Wielkanoc i dzień św. św. Piotra i Pawła, ale - co istotne - nie pomija właśnie anniwersarium papieża Klemensa II w dniu św. Dionizego, ustanawiając go zarazem dniem świątecznym dla całego

${ }^{29}$ Sancti Leonis IX epistolae et decreta, $\mathrm{nr} 75$.

30 O biskupach Rzeszy wynoszonych w latach 1046-1055 przez Henryka III na tron papieski G. Frech, Die deutschen Päpste - Kontinuität und Wandel, w: Die Salier und das Reich, t. 2: Die Reichskirche in der Salierzeit, red. S. Weinfurter, Sigmaringen 1991, s. 303-332; H. Beumann, Reformpäpste als Reichsbischöfe in der Zeit Heinrichs III. Ein Beitrag zur Geschichte des ottonisch-salischen Reichskirchensystems, w: Festschrift Friedrich Hausmann, red. H. Ebner, Gratz 1977, s. 21-37; także G. Gresser, Clemens II. Der erste deutsche Reformpapst, Paderborn 2007.

${ }^{31}$ Die Vita sancti Heinrici regis, s. 257-262.

32 O liturgicznym pierwszeństwie chóru zachodniego, mieszczącego główny ołtarz (,altare occidentalis, quod in eadem ecclesia precipuum est et principale”) dedykowany świętym Piotrowi i Pawłowi oraz Kilianowi, informuje już nota konsekracyjna katedry z 1012 r., zob. Dedicatio ecclesiae s. Petri Babenbergensis, wyd. P. Jaffé, MGH SS, t. 17, Hannoverae 1861, s. 635. Orientowanie chóru głównego na zachód i dedykowanie go św. Piotrowi przywodzi na myśl odwzorowanie układu przestrzennego bazyliki watykańskiej. O uroczystości konsekracji zob. G. Zimmermann, Von Symbolgehalt der Bamberger Domweihe (6. Mai 1012), w: idem, Ecclesia - Franconia - Heraldica. Gesammelte Abhandlungen, Bamberg 1989, s. 1-7. Na temat najstarszych ołtarzy katedralnych także R. Baumgärtel-Fleischmann, Die Altäre des Bamberger Domes von 1012 bis Gegenwart, Bamberg 1987, s. 11-13. 
biskupstwa, natomiast wspomnienie śmierci Henryka II nie zostało już tu w ogóle uwzględnione ${ }^{33}$. Jeszcze mocniej podkreśla to znaczenie papieskiego pochówku dla „rzymskości” biskupstwa bamberskiego, której konsekwencją był element stroju liturgicznego biskupa (paliusz i infuła) oraz jego kanoników (infuły) ${ }^{34}$. Drugą, acz blisko związaną z poprzednią kwestią, tworzącą ścisły kontekst wyróżnienia kanoników infułami, jest relacja fraternitatis samego Leona IX z kanonikami bamberskimi, tak jak w przypadku Władysława Hermana, połączona z posiadaniem prebendy ${ }^{35}$. Zostało to wprost odnotowane w interesującym nas przywileju. Nie wiadomo, czy uzyskał ją już jako papież, np. w czasie niedawnego pobytu, czy może już wcześniej jako biskup Toul. Fakt ten niewątpliwie miał duże znaczenie zarówno dla samego papieża, jak i prestiżu kanoników bamberskich, mogących zaliczać do swej wspólnoty samego biskupa Rzymu ${ }^{36}$.

Analiza mająca przybliżyć nas do odpowiedzi na pytanie o możliwość posługiwania się w Polsce infułami przez wyróżnionych takim przywilejem prałatów kapituły bamberskiej musi uwzględnić także kwestię warunków praktycznej realizacji takich przywilejów. Należy zatem postawić pytanie, gdzie i w jakich okolicznościach biskupi i kanonicy byli uprawnieni do użycia nadanych im przez papieża insygniów liturgicznych. W przypadku tych pierwszych odpowiedź wydaje się dużo łatwiejsza. Dyktat dość ujednoliconych treściowo dokumentów paliuszowych dla arcybiskupów oparty był na formularzu Liber diurnus ${ }^{37}$. Oprócz wspomnianego już wyżej wykazu świąt zawierały one, w przeciwieństwie do dużo mniej licznych przywilejów dla opatów i kanoników, także wyszczególnienie rodzajów liturgicznych wystąpień publicznych arcybiskupa, podczas których mógł on nosić paliusz - takich jak konsekracja kościołów, ordynacja sufraganów i święcenia kleru, depozycja relikwii, przewodniczenie liturgii synodalnej, a nawet święta bardziej osobistej natury,

33 Sancti Leonis IX epistolae et decreta, nr 76.

${ }^{34}$ Paliusza używali też dowodnie niektórzy z następców Hartwiga: Gunter (10571065), który informował o tym w liście skierowanym do arcybiskupa mogunckiego Zygfryda I (Udalrici Babenbergensis codex, w: Bibliotheca rerum Germanicarum, t. 5: Monumenta Bambergensia, wyd. P. Jaffé, Berolini 1869, nr 27), Otto I (1102-1139), który otrzymał paliusz od Paschalisa II w 1111 r. (Udalrici Codex, nr 151), oraz jego następca Egilbert (1139-1146) na mocy przywileju Innocentego II z 1139 r. (Pommersches Urkundenbuch, t. 1, wyd. K. Conrad, Köln-Wien 1970, nr 28).

35 „quin etiam amore et desiderio fratrum, qui nos in suis recepere aecclesiasticis stipendiis et cottidianis, unum nostra vicissitudine regere fratrem", ibidem, nr 75 .

${ }^{36} \mathrm{Na}$ temat fraternitas i kanonikatu papieskiego poza Rzymem A. Schulte, Deutsche Könige, Kaiser und Päpste als Kanoniker an deutschen und römischen Kirchen, „Historisches Jahrbuch" 54, 1934, s. 157-167.

${ }^{37}$ J. Johrendt, op. cit., s. 62-65. 
jak dzień urodzin czy rocznica ordynacji biskupiej3. Wydaje się zatem oczywiste, że arcybiskup mógł celebrować liturgię, używając oznak swojej godności także poza kościołem katedralnym, gdzie z natury rzeczy odbywały się konsekracje kościołów, a często także ordynacja biskupów sufraganów, choć znamienne wydaje się to, iż takie rozszerzenie przywileju bywało przedmiotem interpolacji, jak choćby w podfałszowanym dokumencie Benedykta VIII dla arcybiskupa magdeburskiego Waltarda z 1012 r. ${ }^{39}$ Indywidualne, tj. nadawane dożywotnio i ad personam przywileje dla metropolitów na użycie paliusza i innych oznak władzy metropolitalnej, oprócz ściśle reglamentowanego czasu świątecznego, nie narzucały zatem miejsca ich użycia. Ewentualne nadużywanie nadanych przez Stolicę Apostolską insygniów było traktowane przez papiestwo bardzo poważnie. Około 924 r. papież Jan X z powołaniem się na autorytet Grzegorza Wielkiego odmówił arcybiskupowi kolońskiemu Hermanowi postulowanego przez niego poszerzenia katalogu świąt liturgicznych z użyciem paliusza ${ }^{40}$. Samo dążenie do poszerzania katalogu świąt $\mathrm{z}$ użyciem paliusza w kolejnych przywilejach oraz ich falsyfikatach świadczy, że kwestia ta nabrała dużego znaczenia prestiżowego i stała się elementem rywalizacji pomiędzy arcybiskupami, dążącymi - jak moguncki, trewirski i koloński - do prymatu w kościele Rzeszy lub - jak salzburski, hambursko-bremeński i magdeburski - przynajmniej do zrównania statusu swych metropolii z trzema nadreńsko-lotaryńskimi ${ }^{41}$.

W przypadku kanoników kwestia przedstawiała się jednak zupełnie odmiennie. W przeciwieństwie do biskupów, realizujących rozliczne zadania administracyjne, duszpasterskie i polityczne poza katedrą i stolicą diecezji, a nawet już w XI-XII w. często rezydujących w odległych od niej majątkach biskupstwa, ich podstawowym zadaniem było wykonywanie obowiązków liturgicznych w kościele katedralnym, a w interesującym nas okresie realizowanie $\mathrm{w}$ pełni zasad vitae communis $\mathrm{w}$ ramach katedralnego monasterium kanonickiego, wzorowane na zwyczajach monastycznych i normowane regułą akwizgrańską. Czy jednak ograniczało to w jakikolwiek sposób ich prawo do posługiwania się infułami i innymi elementami stroju liturgicznego wymienianymi w papieskich przywilejach? Dokument Leona IX dla kanoników bamberskich nie udziela na pierwszy rzut oka rozstrzygającej odpowiedzi na pytanie, gdzie występować mogli

${ }^{38}$ T. Zotz, op. cit., s. 171-175.

39 „tam in tua ecclesia, quam in aliis pro neccesitate itineris statutis diebus”, PU, t. 2 , nr 472 .

${ }^{40}$ PU, t. 1, nr 52.

${ }^{41}$ Analizę tego zagadnienia z perspektywy zmian w katalogach świąt przeprowadził T. Zotz, op. cit., s. 158-171. 
oni w infułach. Wyróżniony i szczegółowo określony został tu przede wszystkim czas realizacji owego przywileju - tj. konkretne dni roku liturgicznego. Wskazówka w istocie jednak kryje się w zdaniu o liturgii sprawowanej przy grobie papieża Klemensa II: „Tym zaś nadajemy ową godność, którzy tylko szczególnie czuwają lub służą przy grobie wspomnianego poprzednika naszego" ${ }^{42}$. Można dociekać, czy intencją papieskiego dyktatu z użyciem słów „tantum specialiter” było wyłączne wskazanie papieskiego grobu jako miejsca owej uroczystej liturgii oraz co dokładnie kryje się pod określeniem „apud predicti predecessoris nostri sepulchrum". Dokładna pierwotna lokalizacja miejsca pochówku Klemensa II w obrębie jedenastowiecznego chóru zachodniego katedry bamberskiej nie jest znana. Ponieważ jednak zgon poprzednika Leona IX przypaść miał w dniu św. Dionizego, zasadne będzie uważać, że ołtarz, przy którym odprawiano msze anniwersaryjne, dedykowany był właśnie temu świętemu ${ }^{43}$. Nota konsekracyjna katedry z 1012 r. istotnie lokalizuje ołtarz pod tym wezwaniem w chórze zachodnim, po lewej stronie ołtarza głównego ${ }^{44}$. Być może właśnie w jego sąsiedztwie pochowany został papież Klemens. Rozporządzenie zawarte w dokumencie Leona IX jest jednak na tyle nieprecyzyjne, że nie wykluczało zapewne celebracji liturgii w infułach także przy innych ołtarzach w przestrzeni katedry, a przynajmniej w obrębie jej chóru zachodniego. Wydaje się bowiem wątpliwe, by kanonicy nie mogli używać owych mitr w wyznaczone w przywileju dni, gdy odprawiali modły przy innych ołtarzach, a zwłaszcza dedykowanych świętym patronom katedry, których pamiątkę w danym dniu celebrowali. Tak czy inaczej, już dyspozycja dokumentu Leona IX dość jednoznacznie ogranicza użycie infuł do przestrzeni liturgicznej bamberskiej katedry.

Kwestia przywileju udzielonego kapitule bamberskiej przez papieża znana była tzw. Anonimowi z Herrieden, autorowi kroniki biskupiej z Eichstätt z drugiej połowy XI w..$^{45}$ Jego uzyskanie powiązał on jednak

42 „His vero concedimus hanc dignitatem, qui tantum specialiter excubant vel deserviunt apud praedicti praedecessoris nostri sepulchrum”, Die Vita sancti Heinrici regis, s. 270 .

${ }^{43}$ O liturgii ku czci św. Dionizego związanej z anniwersarium Klemensa II po likwidacji ołtarza, będącej wynikiem trzynastowiecznej przebudowy katedry, zob. G. Gresser, op. cit., s. 130-131.

${ }^{44}$ „Sinistrum altare occidentalis altaris consecravit Megingaudus Treverensis archiepiscopus in honorem sanctorum martirum Dionisii, Rustici et Eleutherii, Laurencii, Ypoliti et Viti", Dedicatio ecclesiae s. Petri, s. 635.

45 „Qui [tj. Klemens II] eisdem Babenbergensibus hoc privilegium dedit, ut in summis festivitatibus tum ministri altaris tum etiam ceteri seniores mitras habeant in capitibus", S. Weinfurter, Die Geschichte der Eichstätter Bischöfe des Anonymus Haserensis. EditionÜbersetzung - Kommentar, Regensburg 1987, Eichstätter Studien, Neue Folge, t. 24, s. 63. 
nie z Leonem IX, lecz z samym Klemensem II, co dało asumpt do przypuszczeń, że to nie jego następca, lecz już umierający papież wyróżnił w ten sposób kościół wybrany na miejsce ostatniego spoczynku, którego biskupem pozostawał ciągle pomimo objęcia godności papieskiej i z którym czuł się szczególnie związany emocjonalnie ${ }^{46}$. Pogląd ten nie posiada innej podstawy źródłowej i nie powinien być brany pod uwagę. We wzmiance Anonima z Herriden warto jednak zwrócić uwagę na inny wątek. Doprecyzowuje on, że przywilej dotyczył w pierwszej kolejności „ministri altaris”, a zatem celebransów liturgii z grona kanoników - prezbitrów, jak i diakonów. To z pewnością potwierdza tylko wątpliwości, czy przywilej ten mógł być ważny - a co więcej, czy miał w ogóle sens poza liturgią sprawowaną w wyznaczone dni świąteczne i anniwersaria przez kanoników w murach własnej katedry. Utwierdzenie się w tym przekonaniu ponownie skłania nas do sięgnięcia po materiał porównawczy.

Nasza uwaga skierować się musi ku całkiem licznej kategorii przywilejów papieskich z X-XII w., tworzących przy wybranych kościołach katedralnych lub kanonickich specjalne kolegia prezbitrów, diakonów, a niekiedy także subdiakonów, odwzorowujące porządek liturgii papieskiej w bazylice św. Jana na Lateranie - a z tego względu niekiedy wprost określanych jako cardinales - uprawnionych do sprawowania liturgii mszalnej z użyciem „rzymskich” elementów stroju, tj. infuł, dalmatyk i sandałów ${ }^{47}$. Najbardziej szczegółowy opis funkcjonowania takiego kolegium odnajdujemy w interpolowanym przywileju paliuszowym dla arcybiskupa Waltarda z 1012 r. oraz innych wytworzonych w tym czasie falsyfikatach magdeburskich: dwunastu kardynałów-prezbitrów miało prawo codziennego używania dalmatyk, w wyznaczone święta zaś także sandałów, natomiast status siedmiu asystujących im kardynałów-diakonów odróżniał się jedynie zakazem używania dalmatyk w okresie Wielkiego Postu. Wszyscy oni celebrowali liturgię „ad maximum altare” katedry magdeburskiej, dedykowanym św. Maurycemu ${ }^{48}$. Podobnie przedstawiała

${ }^{46}$ G. Gresser, op. cit., s. 121-122.

47 Zestawienie pozarzymskich kolegiów kardynalskich - aczkolwiek nieco niepełne, bo nieuwzględniające choćby Bambergu - wraz z syntetyczną charakterystyką tej instytucji daje Carlo G. Fürst, Cardinalis. Prolegomena zu einer Rechtsgeschichte des Römischen Kardinalskollegiums, München 1967, zwł. s. 74-83; zob. też idem, I cardinalati non romani, w: Le istituzioni ecclesiastiche della „Societas Christiana” dei secoli XI-XII. Papato, cardinalato ed episcopato. Atti della quinta Settimana internazionale di studio, Mendola, 26-31 agosto 1971, Milano 1974, s. 185-198, zwł. s. 186-187.

${ }^{48}$ PU, t. 2, nr 472; por. Das Erzbistum Magdeburg, oprac. G. Wentz, B. Schwineköper, t. 1, cz 1: Das Domstift St. Moritz in Magdeburg, Berlin-New York 1972, Germania Sacra, s. 213-214. 
się kwestia w przypadku akwizgrańskiej kapituły pałacowej, w której przywilej Grzegorza V z 997 r. ustanawiał siedmiu kardynałów-prezbitrów i tyluż diakonów, mających obok arcybiskupa Kolonii i biskupa Leodium wyłączne prawo celebracji liturgii przy ołtarzu Bogurodzicy - patronki kapituły ${ }^{49}$. Na szczególną uwagę zasługuje zwłaszcza najbliższy bamberskiemu nie tylko chronologicznie, ale także jeśli chodzi o szczegóły dyspozycji przywilej Leona IX dla kanoników katedry w Besançon z 1051 r. Papież dokonał tam osobistej konsekracji ołtarza św. Szczepana, ustanawiając przy nim siedmiu kardynałów wybranych z grona kapituły, uprawnionych do odprawienia tylko jednej mszy dziennie przy rzeczonym ołtarzu z użyciem mitr, dalmatyk i sandałów. Jednym z owych kardynałów miał być aktualny dziekan kapituły, a przywilej użycia wspomnianych atrybutów dotyczył nie tylko prezbitra celebransa, ale także asystujących diakonów i subdiakonów ${ }^{50}$.

Przykłady powyższe jednoznacznie dowodzą, że zasadniczym celem tego typu przywilejów było podniesienie rangi nie tyle samych kanoników, ile sprawowanej przez nich liturgii przy konkretnym ołtarzu, dedykowanym konkretnemu świętemu. Wyżej wspomniane były natomiast ołtarzami głównymi katedr w Magdeburgu i Besançon oraz w akwizgrańskiej kolegiacie pałacowej. Takim statusem nie cieszył się natomiast bamberski ołtarz św. Dionizego, toteż zasadne wydaje się sądzić, że nie tylko przy nim, ale zwłaszcza przy ulokowanych w obu chórach katedry ołtarzach głównych - św. św. Piotra i Pawła i NP Marii oraz św. Jerzego kanonicy bamberscy odprawiać mogli liturgię w swych infułach. Trzeba zauważyć jednak, że nawet przywileje nie wskazujące konkretnego ołtarza jako miejsca celebracji liturgii kanonickiej z użyciem infuł, dalmatyk

${ }^{49}$ PU, t. 2, nr 340, zob. L. Falkenstein, Otto III und Aachen, Hannover 1998, MGH Studien und Texte, t. 22, s. 84-91. Być może z liturgicznym odwzorowaniem kolegium kardynalskiego przez cesarskie kapituły pałacowe łączyć należy nieco zagadkowe pojawienie się w topografii Akwizgranu, Frankfurtu nad Menem i Ratyzbony (rejon miasta, gdzie zlokalizowana była tzw. Stara Kaplica karolińskiego pfalzu) określenia „Lateran” „Latran” - „Latron”. Z wymienionych tu kapituł jednakże tylko akwizgrańska dysponowała papieskim przywilejem w tej materii, a przynajmniej tylko ten jest zachowany, zob. R. Strobel, J. Sydow, Der „Latron” in Regensburg. Ein Beitrag zum Kontinuitätsproblem, „Historisches Jahrbuch” 83, 1963, s. 1-27; L. Falkenstein, Der Lateran der karolingischen Pfalz zu Aachen, Köln-Graz 1966.

50 „septem e fratribus illius congregationis, qui melioris vite eligantur et cardinales vocentur, quorum unus sit eiusdem ecclesie decanus, et sicut est maior in congregatione, ita prior polleat dignitate. Horum itaque quicumque ibi celebraverit missam, induat dalmaticam, et tunc demum audeat celebrare cum omni reverentia et religione; sandalis quoque utantur et mitra, tam ipse sacerdos, quam diaconus nec non subdiaconus", Sancti Leonis IX epistolae et decreta, nr 53. 
i sandałów precyzowały, że miejscem realizacji owego uprawnienia ma być kościół katedralny. Wątpliwości nie pozostawia pod tym względem sformułowanie użyte w przywileju Paschalisa II dla biskupa i kanoników katedry św. Jakuba w Composteli z 1105 r.: „,w dni świąteczne dostojnicy jego [tj. biskupa Compostelli - M.R.P.] kościoła we wnętrzu świątyni niech nakrywają głowy ozdobnymi mitrami na podobieństwo prezbitrów i diakonów, kardynałów Stolicy Apostolskiej"51. Podobnie we wspomnianym już wyżej dokumencie Aleksandra II dla biskupa Burcharda II i kanoników halbersztadzkich odnajdujemy jednoznaczną wskazówkę, że przyznane im prawo posługiwania się mitrami dotyczyło mszy odprawianych w katedrze - „in maiore ecclesia" 52 .

Przywilej Leona IX dla Bambergu odznacza się z pozoru nieco mniejszą precyzją terminologii i dyspozycji niż analogiczne dokumenty przytoczone powyżej. Nie nazywał wyróżnionych infułami kanoników bamberskich kardynałami, choć w istocie - tak jak inne - odwoływał się w organizacji liturgii wprost do wzorca laterańskiego, oraz bardzo mocno wiązał wyróżnienie liturgiczne kanoników z osobą pochowanego w katedrze papieża Klemensa II. Nie ma zatem powodu sądzić, że stworzył on zasadniczo odmienną rzeczywistość niż ta opisana staranniej w innych podobnych dokumentach papieskich tej doby. Wybrani kanonicy bamberscy - w tym prałaci kapituły katedralnej - nie zostali uhonorowani osobistym przywilejem papieskim, podnoszącym ich indywidualny prestiż w hierarchii duchownej, który upoważniałby ich do zakładania infuł poza liturgią mszalną sprawowaną we własnej katedrze, tak jak miało to miejsce w przypadku używanych przez biskupów paliuszy i racjonałów ${ }^{53}$. Kluczem do zrozumienia sensu tego typu nadań papieskich jest podkreślana w prawie wszystkich przypadkach łączność wyróżnionego kościoła z papiestwem, której widoczną emanacją stać się miała „rzymskość” sprawowanej tam liturgii ${ }^{54}$. W Bambergu tym dodatkowym wyróżnikiem „rzymskości” miejsca stał się pochówek Klemensa II.

51 „in sollempnis diebus maiores ecclesie eius persone intra ecclesiam mitris gemmatis capita contegant, in speciem videlicet presbyterorum seu diaconum sedis apostolice cardinalium", Paschalis II epistolae et privilegia, PL, t. 163, nr 159.

52 ,insuper mitras tibi et successoribus tuis ac canonicis tuis excellentioribus, scilicet presbiteris ac diaconibus et inter missarum sollemnia ministraturis subdiaconibus, in maiore ecclesia tua in suprascriptis festivitatibus portandas concedimus", Urkundenbuch des Hochstifts Halberstadt, nr 83.

${ }^{53} \mathrm{Na}$ temat znaczenia tego ostatniego insygnium w średniowieczu zob. K. Honselmann, Das Rationale der Bischöfe, Paderborn 1975, s. 23-29.

${ }^{54}$ Niewątpliwie najbardziej ewidentnym nawiązaniem do liturgii papieskiej było zezwolenie na używanie konia i kropierza liturgicznego (naccus) w czasie celebracji liturgii stacyjnej, wprost wspomnianej np. w przywileju Jana XI dla arcybiskupa 


\section{Infuła jako insygnium biskupie w XI stuleciu?}

Na podstawowe dla naszego zagadnienia pytanie, czy domniemani prałaci kapituły bamberskiej posłużyć się mogli infułami w czasie legacji w Polsce, udzielić należy odpowiedzi zdecydowanie negatywnej. Konstatacja, że Eberhard i Henryk niewątpliwie byli biskupami, w istocie zwalnia nas od konieczności odniesienia się do pozostałych zasygnalizowanych na wstępie wątpliwości. Dla porządku i dopełnienia obrazu realiów interesującego nas okresu warto poświęcić im jednak nieco uwagi. Należy postawić pytanie, czy u schyłku XI w. możliwe byłoby określenie kanoników-infułatów mianem biskupów tylko i wyłącznie na podstawie faktu liturgicznego posługiwania się przez nich rzeczonymi infułami. Z dwóch powodów wydaje się to niezmiernie mało prawdopodobne.

Przydanie komuś nienależnego tytułu ze względów kurtuazji - bez wątpienia powszechne współcześnie - nie mieściło się jednak w mentalności elity XI w. Tym bardziej, gdy chodziło o najściślej w ówczesnych realiach społecznych zhierarchizowany świat kleru, w wyniku postępów reformy kościelnej coraz silniej oddzielony od laikatu oraz mocno uwarstwiony wewnętrznie nie tylko rytualną hierarchią kilku stopni święceńn ${ }^{55}$, wśród których święcenia biskupie stanowiły poziom najwyższy, ale też niepisanymi regułami honorowej precedencji. Z tymi pierwszymi wiązały się, obok właściwych biskupom form officium divinum, zastrzeżone czynności liturgiczne, pastoralne i jurysdykcyjne, pozostające wyłącznie w gestii biskupa: konsekracja kościołów i ołtarzy, ordynacja duchownych (włącznie z innymi biskupami), bierzmowanie wiernych, absolucja pokutników, konsekracja krzyżma, zwoływanie synodów, sprawowanie sądownictwa kościelnego nad duchowieństwem i świeckimi ${ }^{56}$.

mogunckiego Bardona z 1032 r. - „crucem ante vos portandum fraternitatis vestre concedimus et in stationibus festivis super equum equitandi licentiam damus”, Mainzer Urkundenbuch, t. 1, wyd. M. Stimming, Darmstadt, nr 278. Na temat porządku papieskiej liturgii stacyjnej w XI-XII w. ostatnio zob. Ch. Wickham, Medieval Rome. Stability and Crisis of a City, 900-1150, Cambridge 2015, s. 324-329.

55 Znaczenie hierarchii święceń odzwierciedla choćby rozpowszechniony już w karolińskich podręcznikach dla kleru krótki anonimowy utwór Ordinationes Christi, ilustrujący genezę siedmiu stopni hierarchii kapłańskiej epizodami z żywota Chrystusa, zob. C. van Rhijn, Manuscripts for Local Priests and the Carolingian Reforms, w: Men in the Middle. Local Priests in Early Medieval Europe, red. S. Patzold, eaem, Berlin-Boston 2016 , s. $189-190$.

${ }^{56}$ Sakralne i świeckie źródła legitymizacji władzy biskupów w opiniach kanonistów XI-XIII w. poddał gruntownej analizie w klasycznej pracy Robert L. Benson, The Bishop-Elect. A Study in Medieval Ecclesiastical Office, Princeton 1968. 
Jak poważne konsekwencje dla sakralnego porządku i poprawności rytu niosło dopuszczenie do wykonywania czynności biskupich przez osobę nieposiadającą stosownych święceń, a jedynie za biskupa się podającą, świadczyć może opowieść Kosmasa o pojawieniu się w Czechach fałszywego biskupa. Człowiek ów, imieniem Ruotpert, podawał się za ordynariusza prowansalskiej diecezji Cavaillon. Uwiarygodniony świadectwem jednego z kanoników praskich, którego spotkał na Węgrzech w drodze do Jerozolimy, Ruotpert za zgodą księcia Brzetysława II i biskupa-elekta praskiego Kosmasa nie tylko odprawiał officium divinum wedle rytu episkopalnego, ale także udzielał chrztu, wyświęcał kościoły, ordynował duchownych i konsekrował krzyżmo. Po ujawnieniu oszustwa i zaczerpnięciu informacji w samej diecezji rzekomego biskupa kwestię kanonicznej ważności tych wszystkich czynności rozstrzygnąć musiał sam papież Klemens III, który polecił kościoły konsekrować ponownie, ochrzczonych zaś jedynie bierzmować, a kapłanom udzielić przy okazji najbliższych święceń ponownego błogosławieństwa poprzez nałożenie rąk bez konieczności powtórnej konsekracji ${ }^{57}$. Tak oto - jak konkluduje Kosmas - „rany zadane przez nieprzyjaciela matce kościołowi uzdrowione zostały lekarstwem sprawiedliwości"58. Z naruszeniem zasad honorowej precedencji wiązały się nie mniej poważne konsekwencje, czego najlepszym dowodem jest relacja Lamperta z Hersfeldu o dwóch incydentach, do których doszło w 1063 r. w obecności króla Henryka IV przy okazji celebracji Bożego Narodzenia i Pięćdziesiątnicy w kolegiacie goslarskiej. Stronami stoczonej wewnątrz kościoła bitwy byli ministeriałowie i słudzy opata fuldajskiego oraz biskupa hildesheimskiego, a jej powodem był porządek zasiadania w kolegiacie w czasie nieszporów. Opat Fuldy, powołując się na dawny zwyczaj, zażądał w czasie obrzędu pierwszego miejsca w sąsiedztwie arcybiskupa mogunckiego, które będący na terenie własnej diecezji biskup Hildesheimu uznał za należne sobie ${ }^{59}$.

Osobną kwestią pozostaje u schyłku XI w. sama możliwość prostej i jednoznacznej identyfikacji osoby występującej w infule z biskupem. Dla tworzącego krótko po 1160 r. biografa zamordowanego przez ministeriałów i mieszczan mogunckich arcybiskupa Arnolda z Selenhofen infuła była ukoronowaniem szczegółowo opisanego pontyfikalnego stroju metropolity. Wskazywała ona najdobitniej ze wszystkich elementów liturgicznego

57 Cosmae Pragensis chronica Boemorum, wyd. B. Bretholz, Berolini 1923, MGH SrG n.s., t. 2, ks. 2, r. 51, s. 158-159.

58 ,inflicta ab hoste vulnera matri ecclesie curata sunt antidoto iusticie”, ibidem, s. 159.

${ }^{59}$ Lamperti monachi Hersfeldensis opera, wyd. O. Holder-Egger, Hannoverae-Lipsiae 1894, MGH SrG, t. [38], s. 81-82. 
ubioru na jego kapłańską godność, na podobieństwo do Aarona ${ }^{60}$. Także w dwunastowiecznej ikonografii różnorodnego pochodzenia i rodzaju dominuje już całkowicie i nieodmiennie postać biskupa przedstawianego frontalnie w stroju pontyfikalnym, którego nieodłącznym elementem jest infuła. Wiele wskazuje jednak, że niespełna stulecie wcześniej nie było to jeszcze tak oczywiste. Geneza liturgicznego nakrycia głowy kapłana w kościele zachodnim przed XI w. jest kwestią dość złożoną i pomimo istnienia obszernej literatury przedmiotu jednoznacznie nie wyjaśnioną ${ }^{61}$. Ciągle trudny do rozstrzygnięcia wydaje się wpływ starotestamentowych norm i praktyki stosowania arcykapłańskiego stroju i nakrycia głowy (Wj 28) na chrześcijańskie zwyczaje liturgiczne późnego antyku i wczesnego średniowiecza. Postać Aarona odzianego w liturgiczne szaty jako prefiguracji biskupów odgrywa istotną rolę w dekretałach Pseudo-Izydora $^{62}$, ale ikonograficzne dowody na używanie infuł lub mitr w liturgii są więcej niż wątpliwe. Papieskie przywileje liturgiczne dla biskupów i kanoników zaczynają częściej uwzględniać ceremonialne nakrycia głowy dopiero na krótko przed połową XI w., a analizowany tu przywilej bamberski jest - jak widzieliśmy - jednym z pierwszych świadectw tego rodzaju. Uderza w nich spora niekonsekwencja terminologiczna: obok powszechniejszych terminów mitra i infula spotkać tam można również określenia rzadsze i później nieużywane, jak np. cuphia z przywileju Leona IX dla arcybiskupa mogunckiego Liutpolda ${ }^{63}$. Warto jednak zauważyć, że nieco przeoczony w nauce pozostał jak dotąd fragment listu autorstwa aspirującego do godności metropolitalnej biskupa passawskiego Pilgrima do papieża z ok. 973 r., w którym wśród oznak władzy arcybiskupiej, rzekomo przyznanych przez papiestwo jego poprzednikom, wymienił obok paliusza także infulam pontificalem ${ }^{64}$.

${ }^{60}$ Vita Arnoldi archiepiscopi Moguntinensis. Die Lebensbeschreibung des Mainzer Erzbischofs Arnold von Selenhofen. Edition, Übersetzung und Kommentar, wyd. S. Burkhardt, Regensburg 2014, r. 20, s. 84.

${ }^{61}$ Zob. przede wszystkim: J. Braun, Die liturgische Gewandung im Occident und Orient nach Ursprung und Entwicklung, Verwendung und Symbolik, Darmstadt 1964 (1 wyd. Freiburg/Br. 1907), s. 424 nn.; F. Bock, Geschichte der liturgischen Gewänder des Mittelalters, t. 2, Graz 1970, s. 148 nn.; B. Sirch, Der Ursprung der bischöflichen Mitra und päpstlichen Tiara, St. Ottilien 1975; skrótowo R.E. Reynolds, Clerical Liturgical Vestments and Liturgical Colors in the Middle Ages, w: idem, Clerics in the Middle Ages. Hierarchy and Image, Aldershot 1999, [r. VI], s. 8-10.

${ }^{62}$ H. Beumann, $\mathrm{Zu}$ den Pontifikalinsignien, s. 33-34.

${ }^{63}$ Mainzer Urkundenbuch, t. 1, nr 293.

${ }^{64}$ Codex diplomaticus et epistolaris Regni Bohemiae, t. 1, wyd. G. Friedrich, Praga 19041907 (dalej: CDB), nr 33; zob. także Die Regesten der Bischöfe von Passau, t. 1: 731-1206, red. E. Boshof, München 1992, nr 229. List, który być może nigdy nie trafił do adresata, ma 
$\mathrm{Na}$ dość licznych w okresie późnoottońskim i salickim przedstawieniach kodeksowych biskupów występują oni prawie bez wyjątku z odkrytą głową pomimo konwencjonalnego przedstawiania ich w szatach liturgicznych i zwykle z pastorałem w dłoni. Ograniczając obserwację do obszaru Rzeszy, wskazać tu warto przede wszystkim majestatowy wizerunek arcybiskupa Trewiru Ekberta na miniaturze dedykacyjnej tzw. Psałterza Ekberta (Reichenau, przed 985) ${ }^{65}$, postać tronującego w racjonale na ramionach biskupa mindeńskiego Sigeberta na miniaturze w kodeksie Ordinis missae z drugiej ćwierci XI w. ${ }^{66}$ czy poczet biskupów Eichstätt wyobrażony w pontyfikale Gundekara II $(1071)^{67}$. Jedynym i dość szczególnym odstępstwem od tej reguły jest wyobrażenie mszy św. Erharda w ewangelistarzu opatki Uty z Niedermünster (ok. 1020/1025). Święty patron ratyzbońskiego opactwa kanoniczek wyobrażony został w nakryciu głowy, które jednak w niczym nie przypomina późniejszych mitr biskupich, a raczej turban lub zawój ${ }^{68}$. Trójkątna złota blacha zwisająca $\mathrm{z}$ owego zawoju na czoło postaci biskupa oraz obszerny, sięgający prawie do ziemi, ozdobiony inskrypcjami racjonał w typie efodu, nałożony na ornat i dalmatykę, zdradzają jednoznacznie, że wizerunek biskupa wystylizowany został na podobieństwo starotestamentowego arcykapłana. Obserwacje powyższe potwierdzają coraz liczniejsze w drugiej połowie XI w. wizerunki biskupów na monetach i pieczęciach. Co więcej, insygnium tego nie uwidoczniano nawet w przypadku hierarchów posiadających przywilej papieski na ich używanie, jak arcybiskup trewirski Eberhard (1047-1066) ${ }^{69}$ czy arcybiskup koloński

ścisły związek z wytworzonymi na polecenie Pilgrima falsyfikatami przywilejów papieskich, mającymi dowodzić dawności metropolitalnego statusu Passawy jako następczyni późnoantycznego biskupstwa w Lauriacum (Lorch).

65 Ekbert, Erzbischof von Trier 977-993. Gedenkschrift der Diözese Trier zum 1000. Todestag, red. F.J. Ronig, t. 1, Trier 1993, tab. 34, s. 84.

${ }^{66}$ Zob. J.M. Pierce, Sigebert «the Beloved»: A Liturgical Perspective on Episcopal Image from the Eleventh-Century Minden, w: Envisioning the Bishop. Images and the Episcopacy in the Middle Ages, red. S. Danielson, E.A. Gatti, Turnhout 2014, s. 249-273 oraz il. 10.2.

67 Eichstätt, Diözesanarchiv, Cod. B4, fol. 17v-18r; reprodukcja w: Die Salier. Macht im Wandel, red. L. Heeg, t. 2: Katalog, München 2011, s. 104-105.

${ }^{68}$ Bayerische Staatsbibliothek, Hss. Clm 13601, fol. 4r. Gruntowną analizę treści ideologicznych wizerunku św. Erharda w kontekście pozostałych iluminacji kodeksu przeprowadził ostatnio Hanns Peter Neuheuser, IHPAPXHIA. Zur Auszeichnung von Bischof und Bistumsitz mit der Rationale. Das spätottonische Bischofsbild des Regensburger Uta-Kodex in der Deutung des Hebräerbriefs, w: Bischofsbild und Bischofssitz. Geistige und geistliche Impulse aus regionalen Zentren des Hochmittelalters, red. idem, Münster 2013, Archa Verbi. Subsidia 9, s. 89-133.

${ }^{69}$ Zob. denar - co w naszym kontekście dość istotne - z legendą S PETRUS i S(E)C(VN)DA ROMA - B. Kluge, Deutsche Münzgeschichte von der späten Karolingerzeit bis zum 
Herman II (1036-1056), który w zbliżonych stylistycznie wyobrażeniach na ołowianej bulli i denarze występuje z odkrytą głową ${ }^{70}$.

Zawodność łatwej identyfikacji mitry jako insygnium typowo biskupiego w XI w. potwierdza osobliwy przypadek nadania przez papiestwo prawa do jej używania książętom czeskim Spitygniewowi II i Wratysławowi II. O tym szeroko komentowanym już w literaturze fakcie dowiadujemy się z lakonicznej wzmianki - regestu w zbiorze kanonów kardynała prezbitra Deusdedita, informującym o przyznaniu księciu czeskiemu Spitygniewowi przez papieża Mikołaja II prawa noszenia mitry w zamian za uiszczanie Stolicy Apostolskiej rocznego czynszu wysokości 100 grzywien $^{71}$. Koncesja papieska, datowana na lata 1059-1060, zbiegła się zatem chronologicznie z okresem zwiększonej częstotliwości nadań przywilejów liturgicznych dla kleru. Informacje z regestu Deusdedita potwierdza list Grzegorza VII do Wratysława II z 1073 r., w którym wspomniano o wyróżnieniu Spitygniewa II mitrą, którą jednakże nadać miał nie Mikołaj II, lecz Aleksander II. Pozwala to przypuszczać, że książę zwrócił się do tego ostatniego o potwierdzenie przyznanego już wcześniej insygnium. Treści ideowe i prawne związane $\mathrm{z}$ ową mitrą były przedmiotem licznych naukowych kontrowersji ${ }^{72}$. Prestiżowe znaczenie nakrycia głowy dla władcy czeskiego odzwierciedla zapewne ukazanie go na dwóch typach denarów Wratysława II $^{73}$. Wydaje się jednak, że nie należy go łączyć ani z późniejszym uzyskaniem przez Wratysława II korony królewskiej, ani z konkretnymi uprawnieniami panujących do zwierzchnictwa nad kościołem czeskim. Mitra czeskich książąt odgrywać miała rolę signum intime dilectionis ze strony Stolicy Apostolskiej, a zatem chodziło tu o to samo zaznaczenie bliskiej relacji z papiestwem co w przypadku insygniów nadawanych w tym samym czasie biskupom i kanonikom, choć - jak podkreślił papież w liście do Wratysława II wyróżnienie takie nie zwykło przysługiwać dotąd świeckim ${ }^{74}$.

Ende der Salier (ca. 900 bis 1125), Sigmaringen 1991, tab. 58, nr 346, s. 238-239; tamże miarodajny przegląd ikonografii mennictwa biskupiego w Rzeszy w interesującym nas okresie.

70 R. Kahsnitz, Imagines et signa. Romanische Siegel aus Köln, w: Ornamenta Ecclesiae. Kunst und Künstler der Romanik in Köln, t. 2, red. A. Legner, Köln 1985, s. 26-27 (nr kat. D5); B. Kluge, op. cit., tab. 61, nr 365, s. 244-245.

${ }^{71} \mathrm{CDB}, \mathrm{t} .1$, nr 57.

${ }^{2}$ J. Žemlička, Mitra českých knižat, „Sborník společností přátel starožitností” 3, 1992, s. 17-21.

${ }^{73}$ F. Cach, Nejstarší české mince, t. 2, Praha 1972, nr 347 i 352; J. Hasková, K ikonografii českých mincí Vratislava II., w: Královský Vyšehrad. Sborník příspěvků k 900. výročí úmrtí prvního českého krále Vratislava II. (1061-1092), red. J. Huber i in., Praha 1992, s. 63-64.

${ }^{74}$ CDB, t. 1, nr 64; ostatnio podobnie M. Wihoda, První česká království, Praha 2015, s. $110-114$. 
Zasadnicza zmiana w kwestii biskupiego nakrycia głowy w przedstawieniach plastycznych nastąpiła zatem dopiero po $1100 \mathrm{r}$. Mitry lub infuły w kształcie płaskiej, dwudzielnej, przedzielonej pośrodku pasem czapki lub niskiego lekko wyoblonego stożka zdobią głowy hierarchów przedstawionych na iluminacjach rękopisów sporządzonych w pierwszej ćwierci XII w.: arcybiskupa kolońskiego Fryderyka I (1100-1137) w lekcjonarzu jego fundacji ${ }^{75}$, Brunona trewirskiego (1102-1124) na miniaturze dedykacyjnej Flores epythaphii sanctorum Thiofryda z Echternach ${ }^{76}$ oraz arcybiskupa mogunckiego Rutarda (1089-1109) w würzburskim rękopisie kroniki Ekkeharda z Aury z ok. 1112/1114 r. ${ }^{77}$ Wątpliwości w tej materii również nie pozostawiają dostępne korpusy pieczęci i monet biskupich z XI-XII w. Także na pieczęciach wizerunki hierarchów w mitrach zaczęły pojawiać się dopiero w pierwszej połowie XII w. - np. w przypadku arcybiskupów kolońskich ostrą cezurą jest dopiero pontyfikat Arnolda II z Wied, który na swej pieczęci z 1151 r. jako pierwszy, w przeciwieństwie do wszystkich swych poprzedników, polecił wyobrazić się w infule ${ }^{78}$. Tę zmianę ikonograficzną, ale mająca bezsprzecznie przełożenie na rzeczywistość liturgiczną, doskonale ilustrują trzy zbliżone formalnie typy erfurckich brakteatów arcybiskupa mogunckiego Henryka I (1142-1152) z wyobrażeniem patrona metropolii św. Marcina w górnym polu oraz samego hierarchy jako oranta $\mathrm{w}$ polu dolnym monety. Podstawową różnicą między owymi typami są odkryte głowy obu postaci na typie pierwszym, dwurożna infuła wieńcząca głowę świętego w typie drugim oraz nakrycie głów obu - zarówno świętego, jak i arcybiskupa - takimi samymi dwurożnymi infułami na typie trzecim ${ }^{79}$. Podobne przykłady niekonsekwencji ikonograficznej w typie biskupich wyobrażeń napieczętnych i monetarnych, wynikające z faktu upowszechniania się infuły jako elementu stroju pontyfikalnego dopiero w pierwszej ćwierci XII w., można by jeszcze mnożyć. Proces ten na peryferiach zachodniego chrześcijaństwa mógł trwać nawet nieco dłużej niż w Europie Zachodniej.

W kontekście powyższego wydaje się zatem rzeczą wątpliwą, aby Eberhard i Henryk - już nie jako rzekomi infułaci bamberscy, ale nawet

${ }^{75}$ Köln, Erzbischöfliche Dom- und Diözesanbibliothek, Dom Hs. 59, fol. 1r; reprodukcja w: Die Salier. Macht im Wandel, red. L. Heeg, t. 1: Essays, München 2011, s. 94.

${ }^{76}$ Gotha, Forschungsbibliothek, Memb. I 70, fol. 100r; reprodukcja w: Die Salier. Macht im Wandel, t. 1, s. 84.

77 Cambridge, Corpus Christi College, The Parker Library, CCC Ms 373, fol. 83r; reprodukcja w: Die Salier. Macht im Wandel, t. 2, s. 28.

78 R. Kahsnitz, op. cit., s. 21-33, (nr kat. D11).

79 Die Zeit der Staufer. Geschichte - Kunst - Kultur. Katalog der Ausstellung, t. 1, red. R. Haussherr, Stuttgart 1977, s. 142 (il. t. 2, tab. 102). 
jako biskupi polscy - posługiwali się u schyłku XI w. liturgicznymi nakryciami głowy. Obok świadectw ikonograficznych warta odnotowania jest także nieobecność tego elementu stroju w pontyfikałach. Oba zachowane najstarsze pontyfikały polskie - krakowski z XI w., zachowany w zdekompletowanej formie, oraz płocki z pierwszej połowy XII w., wiązany $\mathrm{z}$ osobą Aleksandra z Malonne - pomimo formuł benedykcji różnych elementów stroju liturgicznego nie zawierają żadnej wzmianki o infule biskupiej czy jakimkolwiek innym nakryciu głowy celebransa ${ }^{80}$. Biorąc pod uwagę ich zależność od dziesiąto- i jedenastowiecznych tekstów zachodnioeuropejskich nie jest to specjalnie zaskakujące, gdyż także tam nie odnajdziemy rzeczonych formul ${ }^{81}$. Podobnie rytuał inauguracji pontyfikatu arcybiskupa, opisany w Consuetudines katedry lundzkiej z 1123 r., przewidywał jedynie założenie przez elekta kapy i akt autoinwestytury poprzez podjęcie przez niego z ołtarza episkopaliów, do których zaliczono jedynie pierścień i pastorał ${ }^{82}$. Ani jednego liturgicznego nakrycia głowy nie wymieniają najstarsze zachowane inwentarze katedry krakowskiej z pierwszej ćwierci XII w., rejestrujące inne elementy stroju liturgicznego ${ }^{83}$. Mitra wraz z rękawicami pojawia się natomiast - co istotne, bez związku z którymkolwiek z biskupów - jako jeden z darów księżnej Salomei z Bergu dla mnichów benedyktyńskiego opactwa Zwiefalten $\mathrm{w}$ latach czterdziestych XII $\mathrm{w} .{ }^{84} \mathrm{~W}$ relatywnie bogatym $\mathrm{w}$ XII $\mathrm{w}$. polskim zestawie wyobrażeń monetarnych świętego Wojciecha - zawsze przedstawianego jako biskup, a w tradycji tego okresu uznawanego już nawet za pierwszego metropolitę Gniezna - mitra nie wystąpiła przed połową XII w. ani razu ${ }^{85}$. Pojawienie się i utrwalenie tego atrybutu wła-

${ }^{80}$ Pontyfikał krakowski z XI wieku, wyd. Z. Obertyński, Lublin 1977, Materiały do Dziejów Kościoła w Polsce, t. 5; Pontyfikat płocki z XII wieku [Bayerische Staatsbibliothek München, Clm 28938, Biblioteka Seminarium Duchownego Płock Mspł. 29]. Studium liturgiczno-źródłoznawcze. Edycja tekstu, oprac. A. Podleś, Płock 1986.

${ }^{81} \mathrm{~J}$. Braun, op. cit., s. 432-434.

82 Consuetudines Lundenses. Statutter for kannikesamfundet $i$ Lund c. 1123, wyd. E. Buus, København 1978, r. 16, par. 83, s. 140.

${ }^{83}$ Edycja: MPH, t. 1, wyd. A. Bielowski, Lwów 1864, s. 376-378; omówienie zawartości L. Kalinowski, Najstarsze inwentarze skarbca katedry krakowskiej jako źródło do dziejów sztuki w Polsce, w: Cultus et cognitio. Studia z dziejów średniowiecznej kultury, red. S.K. Kuczyński i in., Warszawa 1976, s. 217-231.

${ }^{84}$ Zob. S. Wieczorek, Zwiefalten i Polska w pierwszej połowie XII wieku, KH 103, 1996, 4, s. 32, który słusznie powątpiewał w ich użyteczność dla mnichów, gdyż używanie episkopaliów przez opatów benedyktyńskich nie było jeszcze w tym okresie normą.

${ }^{85}$ Biskupi w infułach występują w numizmatyce polskiej dopiero na brakteatach z przełomu XII i XIII w., por. W. Garbaczewski, Ikonografia monet piastowskich 1173-ok. 1280, Warszawa-Lublin 2007, s. 246-257. 
dzy biskupiej nastąpiło także w Polsce po 1150 r. Infuła na głowie biskupa płockiego Aleksandra z Mallone (1129-1156), sportretowanego na spiżowych drzwiach własnej katedry, nie może stanowić istotnego dowodu, gdyż mamy do czynienia z zabytkiem proweniencji magdeburskiej, ale już pieczęć arcybiskupa gnieźnieńskiego Janika (1153), naklejona na jednym z egzemplarzy dokumentu fundacyjnego klasztoru cystersów w Łeknie, świadczy o wejściu liturgicznego nakrycia głowy do stałego użytku metropolity ${ }^{86}$.

\section{Biskupi Eberhard i Henryk w episkopacie polskim przełomu XI i XII w.}

Uznanie Eberharda i Henryka na powrót za biskupów nie zamyka kwestii ich identyfikacji. Już Wojciech Kętrzyński, który pierwszy zwrócił uwagę na dokument Władysława Hermana, uznał ich za biskupów niemieckich, realizujących w Polsce misję dyplomatyczną na zlecenie Henryka IV, a niejako przy okazji odbierających bamberskie krzyże ${ }^{87}$. Badacz zidentyfikował Eberharda jako biskupa Eichstätt, Henryka zaś utożsamił z Henrykiem z Werl, biskupem paderborneńskim lub też współczesnym mu imiennikiem z Fryzyngi. Kluczowa wydaje się zwłaszcza ta pierwsza identyfikacja, gdyż pontyfikat Eberharda z Eichstätt rozpoczął się dopiero po 1099 r., co znacząco zawężałoby czas wystawienia dokumentu do lat 1100-1102, a dodać trzeba, że jest on jedynym o tym imieniu członkiem episkopatu niemieckiego w interesującym nas okresie. Dokładna data objęcia przez niego urzędu nie jest jednak znana, a możliwość określenia go mianem biskupa w Polsce wyklucza raczej fakt, że aż do 1110 r. nie otrzymał on od metropolity mogunckiego święceń biskupich i występował w źródłach jako electus ${ }^{88}$. Wzmacnia to tylko wątpliwości wobec tezy Kętrzyńskiego, które sformułował Wojciechowski, uznając za mało przekonujące, by książę przekazywał swój dar do Bambergu za pośrednictwem niemieckich biskupów. Zastrzeżenie to w pełni podzielam, do czego przyjdzie jeszcze wrócić poniżej.

Osobnego komentarza wymaga także użyte w dokumencie Władysława Hermana określenie „fratres eiusdem ecclesie”. Miał z nim wyraźny kłopot już Wojciechowski, gdy dywagował na temat ewentualnego

86 Dokument fundacyjny klasztoru cysterskiego w Łeknie z roku 1153, red. A.M. Wyrwa, Poznań 2003, s. 27.

87 W. Kętrzyński, Studia nad dokumentami XII wieku, Kraków 1891, s. 113.

${ }^{88}$ Zob. Das Bistum Eichstätt, t. 1: Die Bischofsreihe bis 1535, oprac. A. Wendehorst, Berlin-New York 2006, Germania Sacra N.F., t. 45, s. 71-73. 
połączenia przez obu hierarchów godności biskupiej z kanonikatem w kapitule bamberskiej ${ }^{89}$. Zwrotu tego, jak wiemy, używano jednak również dla podkreślenia trwania relacji braterskiej także po ustanowieniu prałata lub kanonika biskupem w innej diecezji. Choć nie prowadził on już życia we wspólnocie ze swymi dawnymi współbraćmi i nie otrzymywał należnego wiktu i ubioru z tytułu swej dawnej prebendy, zobowiązania modlitewne i komemoracyjne dawnej wspólnoty względem niego nie wygasały. Wskazują na to wyraźne świadectwa podtrzymywania pamięci o biskupach promowanych $\mathrm{z}$ grona kleru kapitulnego $\mathrm{w}$ formie osobnych spisów. Przykładem może tu służyć choćby sporządzona najwyraźniej w celach liturgicznych lista metropolitów i biskupów wywodzących się z kapituły hildesheimskiej zmarłych pomiędzy 949 a 1167 r., poprzedzająca kronikę biskupstwa w jej najstarszym znanym rękopisie ze schyłku XII w. ${ }^{90}$ Podobny spis wyniesionych na biskupstwa kanoników cesarskiej kapituły pałacowej w Goslarze - który nota bene przechował także imię bliżej nieznanego biskupa polskiego Ekkeharda - znany jest tylko z nowożytnego odpisu, choć trudno wątpić, że zapiski tego typu nie mogły powstawać w dużym odstępie czasowym od momentu awansu na biskupstwo, ewentualnie zgonu, wzmiankowanych w nich postaci $^{91}$. Kapituła bamberska - uformowana już wkrótce po założeniu biskupstwa i ciesząca się od początku autonomią majątkową względem biskupów - była w XI w. jednym z najważniejszych ośrodków rekrutacji kadr wyższego kleru w skali całej Rzeszy ${ }^{92}$. Dość wspomnieć, że w ciągu pierwszego półwiecza istnienia biskupstwa na godności biskupie wyniesionych zostało ośmiu jej członków - w tym trzej kolejni prepozyci: Poppo, Pilgrim i Liutpold, awansowani odpowiednio na stolice arcybiskupie w Trewirze (1015), Kolonii (1021) i Moguncji (1051) ${ }^{93}$. Kultywowanie

${ }^{89}$ T. Wojciechowski, op. cit., s. 277.

${ }^{90}$ Chronicon Hildesheimense, wyd. G.H. Pertz, MGH SS, t. 7, Hannoverae 1846, s. 847 848; obszernie na temat funkcji hildesheimskiego katalogu D. Schlochtermeyer, Bistumschroniken des Hochmittelalters. Die politische Instrumentalisierung der Geschichtsschreibung, Paderborn 1998, s. 55-60.

${ }^{91}$ A. Gieysztor, O kilku biskupach polskich XI wieku, w: Europa - Słowiańszczyzna - Polska. Studia ku uczczeniu Profesora Kazimierza Tymienieckiego, red. J. Bardach i in., Poznań 1970, s. 321-324; zwłaszcza H.W. Klewitz, Königtum, Hofkapelle und Domkapitel im 10. und 11. Jahrhundert, „Archiv für Urkundenforschung” 16, 1939, s. 141.

92 O początkach kapituły ostatnio R. Schieffer, Die Anfänge des Bamberger Domkapitels, w:Das Bistum Bamberg um 1007. Festgabe zum Millenium, red.J.Urban, Bamberg 2006, s. 253-268.

93 Zob. zestawienie pochodzenia biskupów niemieckich w: A. Gr. Finck von Finckenstein, Bischof und Reich. Untersuchungen zum Integrationsprozess des ottonisch-frühsalischen Reiches (919-1056), Sigmaringen 1989, s. 194-271; obok nich biskupstwa objęło także dwóch scholastyków bamberskich Durand (Loedium 1021) i Egilbert (Minden 1051), 
braterskiej relacji z podniesionym do godności biskupa lub metropolity kolegami budowało także prestiż macierzystej wspólnoty i było powodem do dumy, jak świadczyć może list gratulacyjny prepozyta i kapituły bamberskiej do Fryderyka, wybranego w 1100 r. na arcybiskupa Kolonii ${ }^{94}$.

Pierwszą możliwą interpretacją terminu fratres w odniesieniu do interesujących nas postaci jest zatem uznanie ich za kanoników bamberskich, awansowanych na biskupstwa polskie w okresie szczególnego - w czym raczej zgodna jest literatura polska od czasów Wojciechowskiego - nasilenia związków personalnych dworu piastowskiego i kościoła z salicką Rzeszą. Przyjmując ten wariant, można by się przychylić do identyfikacji Gieysztora. Chodzić tu mogło rzeczywiście o prałatów kapituły bamberskiej - jej dziekana Eberharda i kustosza Henryka, tyle że nie pełniących już swych funkcji w kapitule. Awans kapitulnych dygnitarzy na stolice biskupie byłby tu - jak widać choćby z powyższego zestawienia - istotnie dużo bardziej prawdopodobny niż szeregowych członków zgromadzenia. Moment ich ostatniego wystąpienia w roli prałatów oraz pojawienia się ich następców w źródłach bamberskich wyznaczałby zatem czas objęcia biskupstw w Polsce. W przypadku Eberharda terminus post quem przypada na rok 1093, ante quem zaś wyznacza pojawienie się w źródłach jego następcy, dziekana Adalberta w 1096 r. ${ }^{95}$ Podobnie rzecz przedstawia się w przypadku Henryka - jako kustosz wystąpił on jeszcze w 1093 r., ale data powołania jego następcy nie jest znana ${ }^{96}$.

Powyższa wykładnia znaczenia relacji fraternitas obu biskupów z kapitułą bamberską nie jest jednakże jedyną możliwością. Wspomniany już wstęp do hildesheimskiej kroniki biskupiej z XII w. pod nagłówkiem: "Nomina ecclesiarum, qui nobis fratres et sorores in Christo" zawiera także wykaz instytucji duchownych w Rzeszy i poza jej granicami, połączonych z kapitułą hildesheimską zobowiązaniami modlitwy za żywych i umarłych ${ }^{97}$. Wśród dziesięciu biskupstw oraz czternastu klasztorów

kustosz Gundekar (Eichstätt 1015), i dwaj kanonicy: Meginhard (Würzburg 1019) i Arnold (Wormacja 1044).

94 „cum filium carissimum sub pennis nostre fraternitatis fotum et altum, in cathedra Coloniensis ecclesie vidimus exaltatum", Udalrici Codex, nr 95.

95 Die Regesten der Bischöfe, nr 567, 573; kommemoracja Eberharda wniesiona do nekrologu michelsberskiego pod 7 września, którą E. von Guttenberg przypisał dziekanowi kapituły, nie jest pewna.

${ }^{96}$ Die Regesten der Bischöfe, nr 567. Powyższej interpretacji nie osłabiają cytowane przez E. von Guttenberga i A. Gieysztora zapisy w nekrologu michelsberskim, gdyż nie zawierają one jednoznacznej wskazówki, że chodzi tu o interesujące nas postacie. Eberhard i Henryk funkcjonują tam bowiem jedynie jako presbyteri, bez oznaczenia funkcji pełnionych w kapitule.

${ }^{97}$ Chronicon Hildesheimense, s. 848. 
mniszych i kanonickich na poczesnym miejscu odnajdujemy Bamberg, a także cztery inne biskupstwa mogunckiej prowincji kościelnej wraz z Pragą. Niestety nie znamy analogicznego wykazu instytucji połączonych tego typu relacją z kapitułą katedralną w Bambergu, ale możemy sądzić, że osoba wywodząca się z takiej instytucji również zostałaby określona jako „frater eiusdem ecclesie”. Wchodzi zatem w grę pochodzenie Eberharda i Henryka z którejś z wpływowych w drugiej połowie XI w. instytucji kościoła cesarskiego. Trzecią opcją - nieco mniej prawdopodobną, jak sądzę - jest zawiązanie indywidualnej relacji braterskiej z kanonikami bamberskimi przez Eberharda i Henryka już po objęciu godności biskupich w Polsce. Instytucjonalne związki braterstwa pomiędzy kapitułami kanonickimi i klasztorami polskimi, choćby ze względu ich w dużej mierze obcoetniczny skład, nie są wprawdzie wykluczone, ale nie dysponujemy na nie wystarczającą liczbą pozytywnych dowodów ${ }^{98}$.

Pozostaje zatem jedynie próba ustalenia, którymi diecezjami polskimi rządzili biskupi wysłani przez Władysława Hermana celem jego przyjęcia do fraternitas z kanonikami bamberskimi. Na to pytanie udzielić można jedynie przybliżonej odpowiedzi. Wojciechowski uznawał hipotetycznie, że mogli oni zasiadać na stolicach biskupich w Płocku i Wrocławiu. Domysł ten uznać można jedynie w połowie za uzasadniony. Biskupstwo wrocławskie posiada bowiem stosunkowo wiarygodny katalog ordynariuszy, prowadzony od reaktywacji diecezji około połowy XII w., którego informacje - najpewniej za sprawą biskupa Roberta przeniesionego w 1142 r. na biskupstwo krakowskie - zostały przeniesione do rocznika kapituły krakowskiej ${ }^{99}$. Pokrywanie się informacji zawartych w katalogach wrocławskich, znanych jedynie w późnośredniowiecznych redakcjach rękopiśmiennych, z zapiskami w krakowskim roczniku dodaje im wiarygodności. Cały okres rządów Władysława Hermana wypełnia wedle tych przekazów długi pontyfikat biskupa Piotra, ustanowionego $\mathrm{w} 1074$, a zmarłego najpewniej dopiero w $1111 \mathrm{r} .{ }^{100}$ Eliminuje to z naszych

${ }^{98}$ Być może np. odnotowanie anniwersarza króla Bolesława Szczodrego w ratyzbońskim opactwie św. Emmerama oraz w nekrologu czeskiego opactwa benedyktyńskiego na Ostrovie jest świadectwem istnienia takich powiązań opactw polskich - Tyńca lub Mogilna - z kręgiem bawarskim, zwłaszcza Ratyzboną i Niederaltaich, skąd wywodził się konwent ostrovski, zob. K. Skwierczyński, Recepcja idei gregoriańskich $w$ Polsce do początku XIII wieku, Wrocław 2005, s. 202-203, oraz P. Wiszewski, op. cit., s. 509-511, 518-524, 537.

99 T. Jurek, Zagadka biskupa wrocławskiego Roberta, Sobótka 45, 1990, s. 8-9; idem, Ryczyn biskupi. Studium z dziejów Kościoła polskiego w XI wieku, RH 60, 1994, s. 26-27.

100 Najdawniejsze roczniki krakowskie i kalendarz, red. Z. Kozłowska-Budkowa,Warszawa 1978, MPH s.n., t. 5, s. 50. 
rozważań diecezję wrocławską. Z podobnych powodów wykluczamy również biskupstwo krakowskie, dla którego również dysponujemy wczesną i uznawaną za wiarygodną listą biskupów ${ }^{101}$. Prawie cały okres panowania Władysława Hermana wypełnia pontyfikat Lamberta ordynowanego w 1082, a zmarłego w 1101 r. Jego bezpośredni następca Czasław, desygnowany na biskupstwo w 1101 r. i złożony z godności dwa lata później przez legata papieskiego Gwalona z Beauvais, nie został wprawdzie odnotowany w katalogu biskupów, ale informacja o jego pontyfikacie zapisana została w najstarszym inwentarzu katedry wawelskiej. Pozostają zatem jedynie biskupstwa w Poznaniu i Płocku jako miejsca sprawowania u schyłku XI w. godności biskupich przez Eberharda i Henryka. Z obu diecezji nie dysponujemy żadnymi wiarygodnymi dla XI w. - a w przypadku Poznania nawet i dla pierwszej połowy XII w. - listami biskupów. Jedyny istniejący katalog biskupów poznańskich autorstwa Jana Długosza zawiera najpewniej aż po połowę XII w. całkowicie fikcyjne - nie licząc Jordana - imiona i biografie tamtejszych ordynariuszy $^{102}$. Nie odnajdziemy tam także znanych z kroniki Anonima „biskupów polskich" Frankona z ok. 1086 r. i współczesnego kronikarzowi Pawła, jednoznacznie identyfikowanych jako poznańscy. Podobnie rzecz przedstawia się z Długoszowym wykazem biskupów płockich: tu wprawdzie uwzględniony został Szymon, wzmiankowany w kronice Anonima Galla, lecz wiarygodność listy jego poprzedników budzi poważne zastrzeżenia. Nawet jeśli uznamy postacie Marka, Stefana i Filipa za historyczne - a na to żadnych dowodów nie mamy - to kompletność owej listy również staje pod znakiem zapytania ${ }^{103}$. Nie istnieją zatem przesłanki pochodzące ze współczesnych źródeł, uniemożliwiające uznanie Eberharda i Henryka za biskupów Płocka i Poznania. Warto przypomnieć, że ostatnie imię pojawia się zresztą dwukrotnie w przekazach odnoszących się do drugiej połowy XI w. Jako „sacerdos et monachus eisdem loci et episcopus Poloniensis" pewien Henryk wpisany został pod datą 8 lipca do nekrologu klasztorów benedyktynów w Siegburgu. Nota nie pozostawia wątpliwości co do jego monastycznej profesji w tym ufundowanym w latach sześćdziesiątych XI w. przez Annona II i należącym do arcybiskupów

101 Zob. A. Wędzki, Lambert II Suła, SSS, t. 3, red. W. Kowalenko i in., cz. 1, Wrocław 1967, s. 13-14; sukcesja biskupów w najstarszym katalogu: Katalogi biskupów krakowskich, wyd. J. Szymański, Warszawa 1974, MPH s.n., t. 10, cz. 2, s. 24, oraz daty pontyfikatu w roczniku kapituły krakowskiej: Najdawniejsze roczniki krakowskie, s. 52-53.

102 J. Długosz, Catalogus episcoporum Posnaniensium, w: Joannis Dlugossii senioris canonici Cracoviensis opera omnia, t. 1, wyd. I. Polkowski, Ż. Pauli, Cracoviae 1887, s. $482-488$.

103 J. Długosz, Catalogus episcoporum Plocensium, w: Joannis Dlugossii opera, t. 1, s. 548. 
kolońskich opactwie ${ }^{104}$. Przyjmując mocno kontrowersyjną w pewnych elementach koncepcję Tadeusza Wasilewskiego, którego zdaniem określenie „episcopus Polonie” wskazuje zawsze na rezydującego w Poznaniu biskupa dworskiego piastowskich władców, można powiązać Henryka $\mathrm{z}$ tą właśnie stolicą diecezjalnąar ${ }^{105}$. Popularność imienia sprawia jednak, że nie mamy żadnej pewności, czy chodzi o tę samą postać. Podobne problemy od dawna sprawia informacja o opacie Henryku i przyszłym arcybiskupie gnieźnieńskim, zawarta w żywocie św. Ottona autorstwa Ebona z Michelsbergu. Według jednej ze znanych autorowi wersji wydarzeń z owym opatem przybyć miał do Polski bohater żywota. Niejednoznaczność zapisu nazwy klasztoru, na którego czele stać miał ów Henryk, sprawia, że nie jesteśmy nawet pewni, czy było to opactwo św. Szczepana w Würzburgu, czy też raczej Wiltzburg koło Ratyzbony, z którym silniej związany był przyszły biskup bamberski i fundator szpitala przy owym zagadkowym klasztorze opata Henryka ${ }^{106}$. W literaturze polskiej przyjmuje się niekiedy tożsamość arcybiskupa Henryka z przekazu Ebona ze wspomnianym biskupem Henrykiem, odnotowanym w nekrologu siegburskim ${ }^{107}$. Stosunek obu tych postaci do biskupa Henryka wzmiankowanego w dokumencie Władysława Hermana pozostaje wysoce niejasny, ale chronologia występowania owych hierarchów w źródłach dopuszcza możliwość ich tożsamości ${ }^{108}$. W granicach prawdopodobieństwa mieści się objęcie przez Henryka najpierw godności biskupa poznańskiego, a następnie metropolity gnieźnieńskiego - to ostatnie być może na bardzo krótko, przed Marcinem, którego pontyfikat według świadectwa Anonima Galla wypełniał sam schyłek panowania Władysława

104 A. Gieysztor, O kilku biskupach, s. 324-325.

105 T. Wasilewski, Kościół monarszy X-XII w. i jego zwierzchnik biskup polski, KH 92, 1985, 4, s. 748-752; gruntowna krytyka koncepcji „biskupstwa dworskiego”, zob.: M.R. Pauk, Capella regia i struktury Kościoła monarszego w Europie Środkowej X-XII wieku. Ottońsko-salickie wzorce ustrojowe na wschodnich rubieżach łacińskiego chrześcijaństwa, w: Granica wschodnia cywilizacji zachodniej w średniowieczu, red. Z. Dalewski, Warszawa 2014, s. 211-277.

106 Ebonis Vita s. Ottonis, wyd. J. Wikarjak, Warszawa 1969, MPH s.n., t. 7, cz. 2, Warszawa 1969, r. 2-3, s. 12-13.

107 T. Wasilewski, op. cit., s. 753.

108 Ze względu na zbyt dużą odległość czasową mało prawdopodobna wydaje się identyfikacja biskupa Eberharda jako byłego opata klasztoru św. Emmerama w Ratyzbonie, wyobrażonego wraz z dwoma innymi opatami tego klasztoru na miniaturze tzw. Ewangeliarza Emmeramskiego, który trafił do Polski najpewniej na przełomie XI i XII w. Rządy opackie Eberharda przypadły bowiem na lata sześćdziesiąte XI w., zob. Das Martyrolog-Necrolog von St. Emmeram zu Regensburg, wyd. E. Freise, D. Geuenich, J. Wollasch, Hannover 1986, MGH Libri memoriales et Necrologia n.s., t. 3, s. 99. 
Hermana. Przeniesienia biskupów z diecezji do diecezji, jeszcze na przełomie X i XI w. traktowane na ogół jako poważne naruszenie przepisów kanonicznych, stawały się w XII w. akceptowaną przez papiestwo normą, a na Węgrzech piastowanie godności biskupiej przed objęciem metropolitalnej da się stwierdzić w przypadku wielu dwunastowiecznych arcybiskupów ostrzyhomskich. Występowanie tej praktyki także w Polsce potwierdza przeniesienie biskupa Roberta z Wrocławia do Krakowa (1142), a także kazus arcybiskupa Janika „Gryfity”, zasiadającego wcześniej na stolicy biskupiej we Wrocławiu (1146-1149) ${ }^{109}$. Niestety równie hipotetyczna, bo ufundowana jedynie na podobieństwie imion, pozostać musi próba utożsamienia interesującego nas biskupa Eberharda z Eckhardem, odnotowanym jako episcopus Polonie w prowadzonym przez kapitułę goslarską wykazie własnych kanoników awansowanych na godności biskupie. Wykaz ten zachował się jedynie we wczesnonowożytnym odpisie, co dopuszcza możliwość błędnej lekcji imienia, a moment ordynacji owego hierarchy wedle ustaleń badaczy owego wykazu przypaść musiał przed 1102 r., co pasuje do okresu aktywności biskupa Eberharda $\mathrm{z}$ dokumentu bamberskiego ${ }^{110}$. Wzajemne powiązania najważniejszych instytucji kościoła cesarskiego - kapituł bamberskiej i goslarskiej, uzasadniałyby także określenie byłego kanonika kolegiaty św. św. Szymona i Judy mianem „brata kościoła bamberskiego”.

Dla przypieczętowania kwestii identyfikacji Eberharda i Henryka jako biskupów polskich zastanowić się wypada nad samym charakterem ich bamberskiej misji. Należy sądzić, że w tak istotnej ideowo dla polskiego władcy sprawie, jak zaliczenie go do grona braci kapituły bamberskiej, był on reprezentowany przez własnych posłów o odpowiednio wysokiej randze, którzy w imieniu księcia osobiście odwieźli cenny dar do Bambergu. Nic zatem dziwnego, że byli nimi dwaj polscy biskupi, dodatkowo związani z miejscem przeznaczenia swej legacji. Wojciechowski w fakcie wysłania $z$ darem książęcym do Bambergu aż dwóch biskupów domyślał się realizowanej przez nich misji dyplomatycznej o celach stricte politycznych ${ }^{111}$. Odpowiedź na pytanie o powody tak wysokiego szczebla polskiego poselstwa kryje się jednak moim zdaniem w samym dokumencie. Książę Władysław, nie mogąc osobiście udać się do Bambergu, delegował dwóch hierarchów najpewniej w celu ceremonialnego dopełnienia rytuału przyjęcia fraternitas kapituły katedralnej. Dobrą analogią dla

109 Zob. J. Dobosz, Arcybiskup Janik ijego następcy. Przygotowanie do reformy Henryka Kietlicza, w: 1000 lat Archidiecezji Gnieźnieńskiej, red. J. Strzelczyk, J. Górny, Gniezno 2000, s. 84-85.

110 A. Gieysztor, O kilku biskupach, s. 321-323.

111 T. Wojciechowski, op. cit., s. 277-279. 
oceny rangi ideowej tego typu wydarzenia jest wizyta cesarza Konrada II w ratyzbońskim opactwie benedyktynek Obermünster w kwietniu $1029 \mathrm{r}$. Przyjęty do wspólnoty modlitewnej mniszek i obdarowany prebendą wraz z żoną i synem, władca pozostawił w klasztorze cesarskie berło dla dodatkowego - obok wystawionego tamże dokumentu - zagwarantowania trwałości swego nadania, będącego podstawą otrzymanych w zamian pożytków duchowych ${ }^{112}$. Możliwy przebieg takiej ceremonii, zrekonstruowany niedawno na podstawie źródeł narracyjnych, dyplomatycznych i liturgicznych przez Wolfganga Ericha Wagnera, zakładał liturgiczne powitanie i goszczenie przybywającego władcy przez konwent, wspólne modły i wymianę pocałunków pokoju, symboliczne złożenie daru lub jego desygnatu (tj. dokumentu lub innego przedmiotu) na ołtarzu, ewentualne wpisanie imienia darczyńcy do księgi brackiej oraz spożycie wspólnego posiłku ze wspólnotą duchownych ${ }^{113}$. Nie wiemy naturalnie, czy dla wysłanników Władysława Hermana zastosowano w Bambergu któryś z elementów takiego rytuału, ale wydaje się niemal pewne, że to właśnie przyjęcie per procura księcia, a zarazem cesarskiego szwagra, do grona braci kapituły było głównym celem wizyty obu biskupów we Frankonii. W istocie zatem odpowiedź na pytanie, kim byli Eberhard i Henryk, kryje się w samym znaczeniu instytucji odnotowanej w dokumencie Władysława Hermana - trudno sobie bowiem wyobrazić, by w tak ważnym religijnie i ideowo momencie polskiego księcia mógł reprezentować ktoś inny niż posłowie odpowiednio wysokiej pozycji, będący biskupami jego kościoła monarszego.

Niniejszy przyczynek do, zdawałoby się, marginalnego i dobrze rozpoznanego zagadnienia ukazuje kilka problemów dużo ogólniejszej natury, związanych ze studiami nad wczesnym średniowieczem Europy Środkowej. W warunkach niezwykłej wprost szczupłości własnego zasobu źródłowego wzbogacenie naszej wiedzy o nowe elementy, ale także weryfikacja starszych poglądów, możliwe są - tak jak w wyżej opisanym przypadku - wyłącznie na podstawie pogłębionego rozpoznania realiów zachodnioeuropejskich. Zwłaszcza w materii studiów kościelno-historycznych niezwykle istotne jest jak najstaranniejsze - a zatem czynione w stałym odniesieniu do postępów badawczych historiografii

112 Conradi II. diplomata, wyd. H. Bresslau, Hannoverae-Lipsiae 1909, MGH Diplomatum regum et imperatorum Germaniae, t. 4, nr 139, s. 187-188; H. Boockmann, op. cit., s. 207-220.

113 W.E. Wagner, op. cit., s. 158-160. 
zachodnioeuropejskiej - rozeznanie w zasadach funkcjonowania struktur władzy i hierarchii kościelnej oraz jej relacji z władzą polityczną, w normach prawa kanonicznego i ich recepcji, jak również w systemie komunikacji obrazowej i rytualnej, znajdującym swój wyraz m.in. w porządku liturgicznym. Postulat ten paradoksalnie wydaje się zarówno oczywisty, jak i zbyt rzadko realizowany w praktyce ${ }^{114}$.

Pomimo zakwestionowania jednego z wyników studiów Gieysztora nad wczesnym episkopatem polskim główne tezy tego autora nie uległy osłabieniu ${ }^{115}$. Stało się wręcz przeciwnie. Środowisko duchownej elity politycznej monarchii piastowskiej w drugiej połowie XI i na początku XII w. pozostawało pod przemożnym wpływem przybyszów z Rzeszy. Ich obecność - teraz ostatecznie zasilona także biskupami Eberhardem i Henrykiem - jest istotnie szczególnie dobrze widoczna w okresie rządów Władysława Hermana. Niewiele niestety da się powiedzieć o drogach ich rekrutacji i karier. Możemy się jedynie domyślać na podstawie rozlicznych analogii obcych, że w promocji cudzoziemców na biskupstwa dużą rolę odgrywała królowa Judyta salicka i jej otoczenie ${ }^{116}$, istotnym

114 Dobrym przykładem całkowicie chybionej próby nowej interpretacji początków arcybiskupstwa gnieźnieńskiego, ufundowanej na podstawie anachronicznych wyobrażeń o znaczeniu paliusza, jest artykuł Przemysława Urbańczyka, Paliusz Gaudentego, w: Viae historicae. Księga jubileuszowa dedykowana Profesorowi Lechowi A. Tyszkiewiczowi, s. 242-260. Istotne wątki swej argumentacji autor oparł na anachronicznym, bo przeniesionym z realiów drugiej połowy XI i XII stulecia założeniu, że już u schyłku X w. przyznanie lub nieprzyznanie paliusza było skutecznym narzędziem centralizmu papieskiego i warunkiem sine qua non wykonywania władzy arcybiskupiej. Tymczasem występowanie o paliusz w tym okresie, niezależnie od „centralistycznej” interpretacji prawno-kanonicznej tego insygnium ze strony papiestwa co najmniej od pontyfikatu Mikołaja I, nie było jeszcze powszechnie obowiązującą normą. O złożoności całej materii związanej z paliuszem świadczy również okoliczność, że - jak wskazałem już wyżej nadanie tego insygnium biskupom nie będącym metropolitami w połowie XI w. nie skutkowało uzyskaniem przez nich dodatkowych kompetencji administracyjno-jurysdykcyjnych, ani nawet egzempcji. Nie zmienia to ponadto faktu, że ordynowany (chyba jako jedyny z metropolitów polskich) w Rzymie Gaudenty najpewniej otrzymał paliusz z rąk samego Sylwestra II już w 999 r. Na temat ewolucji znaczenia i funkcji paliusza arcybiskupiego w X-XI w. ostatnio najobszerniej M. Schrör, Metropolitangewalt und papstgeschichtliche Wende, Husum 2009, s. 76-80 i 140-143; o przemianach w drugiej połowie XI w. zob. także K. Skwierczyński, op. cit., s. 153-155.

115 „Ponieważ większość innych przytoczonych imion «biskupów polskich» wolno położyć na rządy Władysława Hermana, zarysowuje się szczególnie zagęszczony obraz ludzi z obszaru Cesarstwa w jego otoczeniu”, A. Gieysztor, O kilku biskupach, s. 326.

116 O wpływie władczyń na obsadę godności kościelnych zob. A. Fößel, Die Königin im mittelalterlichen Reich. Herrschaftsausübung, Herrschaftsrechte, Handlungsspielräume, Stuttgart 2000, s. 182-190. Promowanie na biskupstwo przez księżnę prałatów z kraju swego pochodzenia widoczne jest dobrze także w Czechach w XII w. 
zaś szczeblem kariery kościelnej, tak jak i gdzie indziej w tym czasie, pozostawała kapella monarsza. Nie przypadkiem ślady pochodzenia przybyszów wiodą do ośrodków kościelnych w Rzeszy silnie związanych z dynastią cesarską - kapituł goslarskiej i bamberskiej. Przewagę liczebną cudzoziemców na polskich biskupstwach nie sposób wyjaśnić wyłącznie - jak to czyni ostatnio Dariusz A. Sikorski - brakiem zainteresowania miejscowych elit karierami kościelnymi, wynikającym ze słabości podstaw materialnych i znaczenia politycznego biskupstw w pierwszym stuleciu ich istnienia ${ }^{117}$. Relatywnie skromne uposażenie biskupstw saskich w IX w. nie miało istotnego wpływu na spore zainteresowanie miejscowej arystokracji obejmowaniem godności biskupich w kraju ${ }^{118}$. Oczywiście istotną rolę odgrywała tu zadziwiająco szybka akulturacja chrześcijaństwa wśród saskiej elity, niewątpliwie pod wpływem wzorców frankijskich, ale chyba nie mniej istotne było niezbyt wielkie zainteresowanie karolińskich władców ścisłą kontrolą obsady biskupstw w tej, peryferyjnej do czasu awansu Liudolfingów, prowincji państwa wschodniofrankijskiego. Utrzymująca się w Polsce aż do początku XIII w. zdecydowana przewaga liczebna obcokrajowców, zwłaszcza na młodszych biskupstwach, ufundowanych po odbudowie organizacji kościelnej, tj. w płockim i kujawskim, także skłania do wniosku, że nie chodziło tu o atrakcyjność materialną. Znane ze współczesnych źródeł uposażenie obu diecezji wskazuje na coś wręcz przeciwnego niż ubóstwo i uzależnienie materialne od władzy książęcej. Konsekwentne powierzanie ich cudzoziemcom, ludziom znacznie bardziej zależnym od łaski panującego niż członkowie rodzimej elity, musiało stanowić zatem element strategii władzy. Było to możliwe zapewne z racji silniejszego patronatu monarszego i powiązania z dworem i kapellą niż w przypadku diecezji starszych ${ }^{119}$.

Instytucjonalne implikacje owej przewagi obcokrajowców z Rzeszy w drugiej połowie XI i na początku XII w. są trudne do oceny ze względów źródłowych. Trudna do rozstrzygnięcia pozostaje w mojej ocenie kwestia inwestytury biskupów polskich w interesującym nas okresie. Nawet jeśli przyjmiemy, że narracja Gallowa oddaje w miarę wiernie

117 A.D. Sikorski, Die Rolle der Geistlichen ausländischer Herkunft in der polnischen Kirche des 10.-12. Jahrhunderts, w: Fernhändler, Dynasten, Kleriker. Die piastische Herrschaft in kontinentalen Beziehungsgeflechten vom 10. bis zum frühen 13. Jahrhundert, red. D. Adamczyk, N. Kersken, Wiesbaden 2015, s. 249-251.

118 Zob. C. Caroll, The Bishoprics of Saxony in the First Century after Christianization, „Early Medieval Europe” 8, 1999, s. 219-245; C. Ehlers, Sachsen als sächsische Bischöfe. Die Kirchenpolitik der karolingischen und ottonischen Könige in einem neuen Licht, w: Streit am Hof im frühen Mittelalter, red. M. Becher, A. Plassmann, Göttingen 2011, s. 95-120.

119 Zob. uwagi dotyczące biskupstwa kujawskiego, M.R. Pauk, op. cit., s. 275-276. 
treść rozstrzygnięć, które zapaść miały w 1000 r. na zjeździe gnieźnieńskim w kwestii pełnej suwerenności polskiego władcy w obsadzaniu swoich biskupstw ${ }^{120}$, to jednak nie jesteśmy w stanie odpowiedzieć na pytanie, czy uznający w pełni zwierzchnictwo cesarskie książęta - jak Kazimierz Odnowiciel, Władysław Herman, a początkowo nawet Bolesław Szczodry - byli skłonni korzystać z uzyskanych kilkadziesiąt lat wcześniej i zapewne kontestowanych w Rzeszy uprawnień. Pamiętać warto, że książęta czescy, pomimo pełnej swobody w decydowaniu o obsadzie godności biskupich w Pradze i Ołomuńcu, aż do schyłku XII w. wysyłali wybranych przez siebie biskupów-elektów na dwór cesarski. Akt wyboru kandydata przez księcia, dokonywany zwyczajowo w przypadku biskupów praskich z zachowaniem pozorów gremialności, nie był zatem tożsamy z aktem inwestytury. Tej ostatniej nie udzielił swoim nominatom nawet Wratysław II, noszący od 1085 r. koronę królewską ${ }^{121}$. Nieobojętna z punktu widzenia obediencji kościelnej biskupa pozostawała także osoba konsekrującego go metropolity. $Z$ tego względu zastanawiać muszą zwłaszcza słowa listu papieża Grzegorza VII do Bolesława Szczodrego o biskupach polskich poszukujących w krajach ościennych konsekratora $\mathrm{z}$ powodu braku własnego arcybiskupa ${ }^{122}$. Być może zatem biskupi polscy drugiej połowy XI stulecia byli w większym stopniu członkami kościoła cesarskiego, niż jesteśmy to w stanie przyznać pod ciężarem tradycyjnej historiograficznej narracji o relacjach polsko-niemieckich, akcentującej głównie ideę suwerenności względem Cesarstwa, bliższą bez wątpienia bardziej dziewiętnastowiecznym doktrynom politycznym niż prawno-ustrojowym realiom schyłku wczesnego średniowiecza.

${ }^{120}$ W ocenie tej relacji brać wypada pod uwagę możliwość stworzenia w kręgu dworu Bolesława Krzywoustego, a być może nawet pod piórem samego Anonima, historiograficznej fikcji na podobieństwo węgierskiej narracji biskupa Györu Hartwiga o rzekomej „apostolskiej legacji” nadanej królowi Stefanowi Świętemu przez papieża Sylwestra II. Ta ostatnia, niewystępująca w starszych żywotach Stefana, stanowić miała ideologiczną podbudowę zwierzchności Arpadów nad kościołem monarszym, podważanej przez papiestwo za pontyfikatu Paschalisa II.

${ }^{121}$ Cosmae chronica Boemorum, ks. 2, r. 49, s. 155-156.

122 Zob. K. Skwierczyński, op. cit., s. 44-45. Trudno tu wszakże rozstrzygnąć, czy słowa papieża odnoszą się do stałego braku metropolity od czasu kryzysu państwa piastowskiego w końcu lat trzydziestych XI w., czy też raczej do jakiegoś przejściowego, choć długotrwałego wakatu na stolicy arcybiskupiej. 


\section{Streszczenie}

Artykuł poświęcony jest problematyce wczesnego episkopatu polskiego i norm liturgicznych XI w. z perspektywy identyfikacji postaci biskupów Eberharda i Henryka. Występują oni w dokumencie księcia Władysława Hermana (1079-1102) dla kapituły bamberskiej jako episcopi i fratres katedry bamberskiej. Uznawani byli dotąd w polskiej literaturze za prałatów kapituły, uprawnionych do używania liturgicznego nakrycia głowy w formie infuł. Autor weryfikuje zasadność tego poglądu na podstawie szerokiej analizy przywilejów papieskich dotyczących użycia insygniów liturgicznych przez biskupów i kanoników w okresie między X a XII w. $\mathrm{W}$ przypadku tych ostatnich celebrowanie liturgii w infułach na wzór kardynałów kurii rzymskiej zastrzeżone było do przestrzeni własnej katedry lub nawet jedynie do konkretnego ołtarza. Liturgia kanoników bamberskich wedle przywileju papieża Leona IX z 1052 r. związana była szczególnie z grobem papieża Klemensa II w zachodnim chórze katedry. Z tego względu Eberharda i Henryka uznać trzeba za biskupów polskich - najpewniej poznańskiego i płockiego, wysłanych do Bambergu celem uroczystego przyjęcia prebendy książęcej w tamtejszej kapitule. Wzmacnia to tezę Aleksandra Gieysztora o przewadze cudzoziemskiego kleru na wysokich godnościach kościelnych w Polsce za rządów Władysława Hermana, tj. w okresie bliskich związków z dworem cesarskim. Autor analizuje także kwestię używania infuły przez biskupów tej epoki, konstatując, że stała się ona stałym insygnium biskupim dopiero od przełomu XI i XII w.

\section{The Episcopate, Liturgy and Politics at the End of the Eleventh Century: Bishops Eberhard and Henry in a Document Issued by Władysław Herman for Bamberg Cathedral}

This article approaches the questions of the early Polish episcopate and eleventh-century liturgical norms from the viewpoint of an identification of bishops Eberhard and Henry. Both men appear as episcopi and fratres of Bamberg cathedral in a document issued by Duke Władysław Herman (1079-1102) for the chapter of Bamberg. Until now Polish literature has recognized them as prelates of the chapter, entitled to wear liturgical headgear in the form of infulas. The author has verified the validity of this view through an extensive analysis of papal privileges permitting the use of liturgical insignia by bishops and canons from the tenth to the twelfth century. In the case of the latter, celebration of the liturgy while wearing infulas in the manner of cardinals of the Roman See was restricted to local cathedrals or even particular altars. The liturgy of the Bamberg canons according to a privilege issued by Pope Leo IX in 1052 was connected in particular with the tomb of Pope Clement II in the western choir of the cathedral. For this reason, Eberhard and Henry should be regarded as Polish bishops - probably of Poznan and Płock, dispatched to Bamberg in order to receive ceremoniously the ducal prebend in the local cathedral chapter. This supposition enforces the thesis proposed by Aleksander Gieysztor about the domination of foreign clergymen in 
high ecclesiastical offices in Poland during the reign of Władysław Herman, a time of close connections with the imperial court. The author also analysed the use of the infula by the bishops of the period and concluded that it did not become their permanent insignia until the turn of the eleventh century.

Translated by Aleksandra Rodzińska-Chojnowska

\section{Bibliografia}

Baumgärtel-Fleischmann, Renate. Die Altäre des Bamberger Domes von 1012 bis Gegenwart. Bamberg: Bayerische Verlagsanstalt, 1987.

Benson, Robert Louis. The Bishop-Elect. A Study in Medieval Ecclesiastical Office. Princeton: Princeton University Press, 1968.

Benyskiewicz, Krzysztof. Władysław Herman ksiażę Polski 1079-1102. Kraków: Avalon, 2014.

Benz, Karl-Josef. Untersuchungen zur politischen Bedeutung der Kirchweihe unter Teilnahme der deutschen Herrscher im hohen Mittelalter. Ein Beitrag zum Studium des Verhältnisses zwischen weltlicher Macht und kirchlicher Wirklichkeit unter Otto III. und Heinrich II., Kallmünz: Verlag Michael Lassleben, 1975.

Beumann, Helmut. „Reformpäpste als Reichsbischöfe in der Zeit Heinrichs III. Ein Beitrag zur Geschichte des ottonisch-salischen Reichskirchensystems". W Festschrift Friedrich Hausmann, red. Herwig Ebner, 21-37. Gratz: Akademische Drucku. Verlagsanstalt, 1977.

Beumann, Helmut. Theutonum nova metropolis. Studien zur Geschichte des Erzbistums Magdeburg in ottonischer Zeit. Quellen und Forschungen zur Geschichte Sachsen-Anhalts, t. 1. Köln: Böhlau, 2000.

Beumann, Helmut. ,Zu den Pontifikalinsignien und zum Amtsverständnis der Bischöfe von Halberstadt im hohen Mittelalter". Sachsen und Anhalt 18 (1994): 9-25.

Bock, Franz. Geschichte der liturgischen Gewänder des Mittelalters. T. 2. Graz: Akademische Druck- und Verlagsanstalt, 1970.

Boockmann, Hartmut. „Eine Urkunde Konrads II. für das Damenstift Obermünster in Regensburg. $\mathrm{Zu}$ einem verschenkten Königsszepter und zum Königskanonikat". W Institutionen, Kultur und Gesellschaft im Mittelalter. Festschrift für Josef Fleckenstein zu seinem 65. Geburtstag, red. Lutz Fenske, Werner Rösener, Thomas Zotz, 207-220. Sigmaringen: Thorbecke, 1984.

Boshof, Egon. Das Erzstift Trier und seine Stellung zu Königtum und Papsttum im ausgehenden 10. Jahrhundert. Der Pontifikat des Teoderich. Köln: Böhlau, 1972.

Braun, Joseph. Die liturgische Gewandung im Occident und Orient nach Ursprung und Entwicklung, Verwendung und Symbolik. Darmstadt: Wissenschaftliche Buchgesellschaft, 1964.

Cach, Ferdinand. Nejstarši české mince. T. 2. Praha: Česká numismatická společnost v Praze, 1972.

Caroll, Christopher. „The Bishoprics of Saxony in the First Century after Christianization". Early Medieval Europe 8 (1999): 219-245.

Derwich, Marek. „Kanonicy świeccy, Bolesław Chrobry i Magdeburg. Ze studiów nad «zapomnianą» instytucją kościelną". W Viae historicae. Księga jubileuszowa 
dedykowana Profesorowi Lechowi A. Tyszkiewiczowi w siedemdziesiata rocznice urodzin, red. Mateusz Goliński, Stanisław Rosik, 233-241. Wrocław: Wydawnictwo Uniwersytetu Wrocławskiego, 2001.

Dobosz, Józef. „Arcybiskup Janik i jego następcy. Przygotowanie do reformy Henryka Kietlicza”. W 1000 lat Archidiecezji Gnieźnieńskiej, red. Jerzy Strzelczyk, Janusz Górny, 81-96. Gniezno: Gaudentinum, 2000.

Ehlers, Caspar. „Sachsen als sächsische Bischöfe. Die Kirchenpolitik der karolingischen und ottonischen Könige in einem neuen Licht". W Streit am Hof im frühen Mittelalter, red. Matthias Becher, Alheydis Plassmann, 95-120. Göttingen: Akademie der Wissenschaften, 2011.

Falkenstein, Ludwig. Der Lateran der karolingischen Pfalz zu Aachen. Köln: Böhlau, 1966.

Falkenstein, Ludwig. Otto III und Aachen. MGH Studien und Texte, t. 22. Hannover: Hahnsche Buchhandlung, 1998.

Finck von Finckenstein, Albrecht Graf. Bischof und Reich. Untersuchungen zum Integrationsprozess des ottonisch-frühsalischen Reiches (919-1056). Sigmaringen: Thorbecke, 1989.

Fleckenstein, Josef. „Rex canonicus. Über Entstehung und Bedeutung des mittelalterlichen Königskanonikates". W Ordnungen und formende Kräfte des Mittelalters. Ausgewählte Beiträge, 193-210. Göttingen: Vandenhoeck \& Ruprecht, 1989.

Fößel, Amalie. Die Königin im mittelalterlichen Reich. Herrschaftsausübung, Herrschaftsrechte, Handlungsspielräume. Stuttgart: Thorbecke, 2000.

Frech, Gustl. „Die deutschen Päpste - Kontinuität und Wandel”. W Die Salier und das Reich. T. 2, Die Reichskirche in der Salierzeit, red. Stefan Weinfurter, 303-332. Sigmaringen: Thorbecke, 1991.

Fürst, Carlo Guido. „I cardinalati non romani”. W Le istituzioni ecclesiastiche della „Societas Christiana” dei secoli XI-XII. Papato, cardinalato ed episcopato. Atti della quinta Settimana di studio, Mendola, 26-31 agosto 1971, 185-198, Milano: Vita e Pensiero, 1974.

Fürst, Carlo Guido. Cardinalis. Prolegomena zu einer Rechtsgeschichte des Römischen Kardinalskollegiums. München: Wilhelm Fink Verlag, 1967.

Garbaczewski, Witold. Ikonografia monet piastowskich 1173-ok. 1280. Warszawa: Polskie Towarzystwo Numizmatyczne, 2007.

Gieysztor, Aleksander. „Bamberg i Polska w XI i XII wieku”. Studia Źródłoznawcze 15 (1970): 71-83.

Gieysztor, Aleksander. „O kilku biskupach polskich XI wieku”. W Europa - Stowiańszczyzna - Polska. Studia ku uczczeniu Profesora Kazimierza Tymienieckiego, red. Juliusz Bardach i in., 311-326. Poznań: Uniwersytet im. Adama Mickiewicza, 1970.

Gresser, Georg. Clemens II. Der erste deutsche Reformpapst. Paderborn: Wilhelm Fink Verlag, 2007.

Groten, Manfred. „Von dem Gebetsverbrüderung zum Königskanonikat. Zu Vorgeschichte und Entwicklung der Königskanonikate an den Dom- und Stiftskirchen des Deutschen Reiches". Historisches Jahrbuch 103 (1983): 1-34.

Hasková, Jarmila. „K ikonografii českých mincí Vratislava II.”. W Královský Vyšehrad. Sborník přispěvkủ k 900. výročí úmrtí prvniho českého krále Vratislava II. (1061-1092), red. Jiř́ Huber i in., 59-68. Praha: Královská kolegiátní kapitula sv. Petra a Pavla na Vyšehradě, 1992. 
Heeg, Laura, red. Die Salier. Macht im Wandel. T. 1, Essays. München: Edition Minerva, 2011.

Hoffmann, Hartmut. Mönchskönig und rex idiota. Studien zu Kirchenpolitik Heinrichs II und Konrads II. MGH Studien und Texte, t. 8. Hannover: Hahnsche Buchhandlung, 1993.

Honselmann, Klemens. Das Rationale der Bischöfe. Paderborn: Wilhelm Fink Verlag, 1975. Johrendt, Jochen. Papsttum und Landeskirchen im Spiegel der päpstlichen Urkunden (8961046). MGH Studien und Texte, t. 33. Hannover: Hahnsche Buchhandlung, 2004.

Jurek, Tomasz. „Początki dokumentu polskiego”. W Dyplomatyka staropolska, red. Tomasz Jurek, 64-87. Warszawa: DiG, 2015.

Jurek, Tomasz. „Ryczyn biskupi. Studium z dziejów Kościoła polskiego w XI wieku”. Roczniki Historyczne 60 (1994): 21-66.

Jurek, Tomasz. „Zagadka biskupa wrocławskiego Roberta”. Ślaski Kwartalnik Historyczny „Sobótka” 45 (1990/92): 1-11.

Kalinowski, Lech. „Najstarsze inwentarze skarbca katedry krakowskiej jako źródło do dziejów sztuki w Polsce". W Cultus et cognitio. Studia z dziejów średniowiecznej kultury, red. Stefan K. Kuczyński i in., 217-231. Warszawa: Państwowe Wydawnictwo Naukowe, 1976.

Kahsnitz, Reiner. „Imagines et signa. Romanische Siegel aus Köln”. W Ornamenta Ecclesiae. Kunst und Künstler der Romanik in Köln, red. Anton Legner. T. 2, 21-59. Köln: Schnutgen Museum, 1985.

Kętrzyński, Wojciech. Studia nad dokumentami XIII wieku. Kraków: PAU, 1891.

Kleinen, Michael. Bischof und Reform. Burchard II von Halberstadt (1059-1088) und die Klosterreform. Husum: Matthiesen, 2004.

Klewitz, Hans Walther. „Königtum, Hofkapelle und Domkapitel im 10. und 11. Jahrhundert". Archiv für Urkundenforschung 16 (1939): 102-156.

Kluge, Bernd. Deutsche Münzgeschichte von der späten Karolingerzeit bis zum Ende der Salier (ca. 900 bis 1125). Sigmaringen: Thorbecke, 1991.

Kozłowska-Budkowa, Zofia. Repertorium polskich dokumentów doby piastowskiej. Z. 1, Do końca wieku XII. Wyd. 2. Kraków: Societas Vistulana, 2006.

Krawiec, Adam. Król bez korony. Władysław I Herman książę polski. Warszawa: Wydawnictwo Naukowe PWN, 2014.

Looshorn, Johann. Die Geschichte des Bistums Bamberg. T. 1. München: P. Zipperer, 1886.

Michałowski, Roman. „Bolesław Chrobry bratem kanoników magdeburskich. Próba nowego spojrzenia". Kwartalnik Historyczny 112, nr 3 (2005): 55-68.

Michałowski, Roman. Princeps fundator. Studium z dziejów kultury politycznej w Polsce X-XIII wieku, Warszawa: Zamek Królewski w Warszawie, 1993.

Michałowski, Roman. Zjazd gnieźnieński. Religijne przesłanki powstania arcybiskupstwa gnieźnieńskiego. Wrocław: Wydawnictwo Uniwersytetu Wrocławskiego, 2005.

Neuheuser, Hanns Peter. „IHPAPXHIA. Zur Auszeichnung von Bischof und Bistumsitz mit der Rationale. Das spätottonische Bischofsbild des Regensburger Uta-Kodex in der Deutung des Hebräerbriefs". W Bischofsbild und Bischofssitz. Geistige und geistliche Impulse aus regionalen Zentren des Hochmittelalters, red. Hanns Peter Neuheuser, 89-133. Archa Verbi. Subsidia, 9. Münster: Aschendorff Verlag, 2013.

Pauk, Marcin Rafał. „Capella regia i struktury Kościoła monarszego w Europie Środkowej X-XII wieku. Ottońsko-salickie wzorce ustrojowe na wschodnich rubieżach 
łacińskiego chrześcijaństwa". W Granica wschodnia cywilizacji zachodniej w średniowieczu, red. Zbigniew Dalewski, 211-277. Warszawa: Instytut Historii PAN, 2014. Pflefka, Sven. „Auf dem Weg zur Exemtion. Die Privilegierung der Bamberger Kirche im 11. und frühen 12. Jahrhundert". Berichte des Historischen Vereins Bamberg 138 (2002): 139-169.

Pierce, Joanne M. „Sigebert «the Beloved»: A Liturgical Perspective on Episcopal Image from the Eleventh-Century Minden". W Envisioning the Bishop. Images and the Episcopacy in the Middle Ages, red. Sigrid Danielson, Evan A. Gatti, 249-274. Turnhout: Brepols, 2014.

Reynolds, Roger Edward. Clerics in the Middle Ages. Hierarchy and Image. Aldershot: Ashgate, 1999.

Rhijn, Carine van. „Manuscripts for Local Priests and the Carolingian Reforms”. W Men in the Middle. Local Priests in Early Medieval Europe, red. Steffen Patzold, Carine van Rhijn, 177-198. Berlin: Walter de Gruyter, 2016.

Schieffer, Rudolf. „Die Anfänge des Bamberger Domkapitels”. W Das Bistum Bamberg um 1007. Festgabe zum Millenium, red. Joseph Urban, 253-268. Bamberg: Archiv des Erzbistums Bamberg, 2006.

Schlochtermeyer, Dirk. Bistumschroniken des Hochmittelalters. Die politische Instrumentalisierung der Geschichtsschreibung. Paderborn: Wilhelm Fink Verlag, 1998.

Schrör, Matthias. Metropolitangewalt und papstgeschichtliche Wende. Husum: Matthiesen, 2009.

Schulte, Alois. „Deutsche Könige, Kaiser und Päpste als Kanoniker an deutschen und römischen Kirchen". Historisches Jahrbuch 54 (1934): 157-167.

Seegrün, Wolfgang. Das Erzbistum Hamburg in seinen älteren Papsturkunden. Köln: Böhlau, 1976.

Sikorski, Dariusz Andrzej. „Die Rolle der Geistlichen ausländischer Herkunft in der polnischen Kirche des 10.-12. Jahrhunderts". W Fernhändler, Dynasten, Kleriker. Die piastische Herrschaft in kontinentalen Beziehungsgeflechten vom 10. bis zum frühen 13. Jahrhundert, red. Dariusz Adamczyk, Norbert Kersken, 241-262. Wiesbaden: Harrassowitz Verlag, 2015.

Sirch, Bernhard. Der Ursprung der bischöflichen Mitra und päpstlichen Tiara. St. Ottilien: Eos Verlag, 1975.

Skwierczyński, Krzysztof. Recepcja idei gregoriańskich w Polsce do początku XIII wieku. Wrocław: Wydawnictwo Uniwersytetu Wrocławskiego, 2005.

Strobel, Reinhard, Jürgen Sydow. „Der «Latron» in Regensburg. Ein Beitrag zum Kontinuitätsproblem". Historisches Jahrbuch 83 (1963): 1-27.

Strzelczyk, Jerzy. „Bamberg a Polska w średniowieczu”. Roczniki Historyczne 62 (1996): 72-88.

Szymański, Józef. Nauki pomocnicze historii. Warszawa: Wydawnictwo Naukowe PWN, 2001.

Urbańczyk, Przemysław. „Paliusz Gaudentego”. W Viae historicae. Ksiega jubileuszowa dedykowana Profesorowi Lechowi A. Tyszkiewiczowi, red. Mateusz Goliński, Stanisław Rosik, 242-260. Wrocław: Wydawnictwo Uniwersytetu Wrocławskiego, 2001. Wagner, Wolfgang Erich. Die liturgische Gegenwart des abwesenden Königs. Gebetsverbrüderung und Herrscherbild im frühen Mittelalter. Brill's Series on the Early Middle Ages, t. 19. Leiden: Brill, 2010. 
Wasilewski, Tadeusz. „Kościół monarszy X-XII w. i jego zwierzchnik biskup polski”. Kwartalnik Historyczny 92, nr 4 (1985): 747-768.

Wickham, Chris. Medieval Rome. Stability and Crisis of a City, 900-1150. Cambridge: Cambridge University Press, 2015.

Weinfurter, Stefan. Die Geschichte der Eichstätter Bischöfe des Anonymus Haserensis. Edition - Übersetzung - Kommentar. Eichstätter Studien, Neue Folge, t. 24. Regensburg: Friedrich Pustet, 1987.

Wendehorst, Alfred, oprac. Das Bistum Eichstätt. T. 1, Die Bischofsreihe bis 1535. Germania Sacra N.F., t. 45. Berlin: Walter de Gruyter, 2006.

Wentz, Gottfried, Berent Schwineköper, oprac. Das Erzbistum Magdeburg. T. 1, cz. 1, Das Domstift St. Moritz in Magdeburg. Germania Sacra. Berlin: Walter de Gruyter, 1972.

Wędzki, Andrzej. „Lambert II Suła”. W Słownik starożytności słowiańskich. T. 3, cz. 1, red. Władysław Kowalenko i in., 13-14. Wrocław: Ossolineum, 1967.

Wieczorek, Szymon. „Zwiefalten i Polska w pierwszej połowie XII wieku”. Kwartalnik Historyczny 103, nr 4 (1996): 23-55.

Wihoda, Martin. První česká království. Praha: Argo, 2015.

Wiszewski, Przemysław. Domus Bolezlai. W poszukiwaniu tradycji dynastycznej Piastów (do około 1138 roku). Wrocław: Wydawnictwo Uniwersytetu Wrocławskiego, 2008.

Wojciechowski, Tadeusz. Szkice historyczne jedenastego wieku. Wyd. 3. Warszawa: Państwowy Instytut Wydawniczy, 1951.

Wolter, Heinz. „Das Privileg Leos IX. Für die Kölner Kirche vom 7. Mai 1052 (JL. 4271)". W Egon Boshof, Heinz Wolter, Rechtsgeschichtlich-diplomatische Studien zu frühmittelalterlichen Papsturkunden, 101-157. Köln: Böhlau, 1976.

Die Zeit der Staufer. Geschichte - Kunst - Kultur. Katalog der Ausstellung. T. 1, red. Reiner Haussherr. Stuttgart: Württembergisches Landesmuseum, 1977.

Zimmermann, Gerd. „Von Symbolgehalt der Bamberger Domweihe (6. Mai 1012)”. W Ecclesia - Franconia - Heraldica. Gesammelte Abhandlungen, 1-7. Bamberg: Selbstverl, 1989.

Zotz, Thomas. „«Pallium et alia quaedam archiepiscopatus insignia». Zum Beziehungsgefüge und zu Rangfragen der Reichskirchen im Spiegel der päpstlichen Privilegierung des 10. und 11. Jahrhunderts". W Festschrift für Berent Schwineköper, red. Helmut Maurer, Hans Patze, 155-175. Sigmaringen: Thorbecke, 1982. Žemlička, Josef. „Mitra českých knížat”. Sbornik společností přátel starožitností 3 (1992): 17-22.

Ilustracja z ewangelistarza Uty z Niedermünster (Bayerische Staatsbibliothek, Hss. Clm 13601, http://daten.digitale-sammlungen.de/ db/0007/bsb00075075/ images/index.html?fip=193.174.98.30\&seite=11\&pdfseitex=).

Biogram: Marcin R. Pauk - adiunkt w Zakładzie Historii Średniowiecznej Instytutu Historycznego UW, specjalizuje się w historii społeczeństw, ustroju, kultury religijnej i ideologii władzy w Europie Środkowej i Rzeszy Niemieckiej X-XIII w., marcinpauk@poczta.onet.pl. 